\title{
Ebastine in the light of CONGA recommendations for the development of third-generation antihistamines
}

This article was published in the following Dove Press journal:

Journal of Asthma and Allergy

28 August 2009

Number of times this article has been viewed

\author{
S Ricol,2 \\ RM Antonijoan ${ }^{1,3}$ \\ MJ Barbanoj $j^{1,2,3}$ \\ 'Centre d'Investigació de \\ Medicaments, Institut de Recerca; \\ Servei de Farmacologia Clínica, \\ Hospital de la Santa Creu i Sant Pau, \\ Barcelona, Spain; ${ }^{2}$ Departament de \\ Farmacologia i Terapèutica, Universitat \\ Autònoma de Barcelona, Barcelona, \\ Spain; ${ }^{3}$ Centro de Investigación \\ Biomédica en Red de Salud Mental \\ CIBERSAM, Spain
}

Correspondence: MJ Barbanoj Centre d'Investigació de Medicaments, Institut de Recerca; Servei de Farmacologia Clínica, Hospital de la Santa Creu i Sant Pau, Avda. Sant Antoni Maria Claret, 167, Barcelona, 08025, Spain $\mathrm{Tel}+34932919019$

Fax +34932919286

Email mbarbanoj@santpau.cat

\begin{abstract}
In 2003 a consensus group on new-generation antihistamines (CONGA) defined the characteristics required for a third-generation $\mathrm{H}_{1}$ antihistamine as there had been much controversy about this issue since the early 1990s. One of the antihistamines that had been claimed to belong to such a group is the second-generation antihistamine, ebastine. The objective of this review is to analyze the pharmacology of ebastine, in light of the CONGA recommendations for the development of new-generation antihistamines: (1) anti-inflammatory properties, (2) potency, efficacy and effectiveness, (3) lack of cardiotoxicity, (4) lack of drug interactions, (5) lack of CNS effects, and (6) pharmacological approach. Ebastine seems to have anti-inflammatory properties that help to ameliorate nasal congestion, though this has not yet been conclusively demonstrated. Its pharmacological-therapeutic profile does not differ greatly from that of other second-generation antihistamines. Its cardiac safety has been widely assessed and no cardiac toxicity has been found at therapeutic doses despite initial concerns. The risk of potentially relevant drug interactions has been investigated and ruled out. Ebastine does not produce sedation at therapeutic doses and drug interaction studies with classical CNS depressants have not demonstrated a synergistic effect. Pharmacologically, ebastine is an $\mathrm{H}_{1}$ inverse agonist. Perhaps the answer to the quest for new-generation antihistamines lies not only in $\mathrm{H}_{1}$ but in a combined approach with other histamine receptors.
\end{abstract}

Keywords: ebastine, antihistamines, third-generation, CONGA, allergy

\section{Introduction}

Allergic diseases are among the commonest causes of chronic ill health. ${ }^{1}$ Discovered in the early 20th century, histamine is one of the major mediators of allergic reactions..$^{2,3}$ The work of the Swiss-Italian pharmacologist Daniel Bovet led to the discovery and production of $\mathrm{H}_{1}$ receptor antihistamines for allergy relief and earned him the Nobel Prize for physiology or medicine in $1957 .{ }^{4}$ The first antihistamine, $929 \mathrm{~F}$ (thymo-ethyl-diethylamine), was identified by Bovet and Staub in 1937,,6 and since then there have been great advances in the development of more efficacious and safer antihistamines. Throughout the last decades, these drugs have been clearly differentiated in first- and second-generation antihistamines.

First-generation antihistamines, such as chlorpheniramine, diphenhydramine, promethazine, and hydroxyzine, are characterized by their high $\mathrm{H}_{1}$ receptor blocking power, and in spite of their side-effect profile they are still widely used. ${ }^{7}$ One of their major downsides is their lack of selectivity for the $\mathrm{H}_{1}$ receptor as they are able to bind to acetylcholine and serotonin receptors and calcium channels. ${ }^{8}$ Furthermore, their lipophilic nature allows them to cross the blood-brain barrier, causing side-effects 
such as decreased alertness, impairment of reaction times, decreased vigilance, and sedation. ${ }^{9}$

Second-generation antihistamines, such as terfenadine, fexofenadine, loratadine, desloratadine, cetirizine, levocetirizine, ebastine, rupatadine, and bilastine, do not penetrate the blood-brain barrier and so provoke minimal central nervous system (CNS) effects. They have greater receptor specificity, with little or no affinity for muscarinic cholinergic receptors. In addition, some second-generation antihistamines exhibit properties, such as anti-inflammatory and analgesic activity, on systems other than $\mathrm{H}_{1}$ receptors. ${ }^{7}$ These properties and other pharmacochemical and pharmacokinetic differences among second-generation antihistamines are responsible for the emergence of the controversial term "third-generation" antihistamines for newer drugs.

Although second-generation antihistamines have been a clear step forward in the treatment of allergic diseases, they have not been devoid of problems. Cardiotoxicity has been a major issue, provoking the withdrawal of terfenadine and astemizole, for example, from the market ${ }^{10,11}$ and introducing the requirement of formal cardiac safety assessment in the drug development paradigm. ${ }^{12,13}$ Moreover, it has been demonstrated that some second generation antihistamines may cause somnolence, ${ }^{14}$ especially when used at supratherapeutic doses. ${ }^{9,15}$

In spite of the knowledge we have acquired over the past few decades, the search for the optimal antihistamine drug continues. ${ }^{16}$ Coined in 1990 , the terms third-generation ${ }^{17}$ or "multifunctional" antihistamines have been used laxly and inappropriately. As a result, in 2003, a consensus group on new-generation antihistamines (CONGA), led by Dr Holgate, provided recommendations on the development of new antihistamines. ${ }^{7}$

To date, no antihistamine drug has fulfilled all the criteria proposed by Holgate et al. ${ }^{7}$ However, some drugs, such as ebastine, appear to offer advantages that represent a step forward in the development of these so-called third generation antihistamines.

In this review we look critically at the information available on ebastine in the light of the CONGA criteria and present current information on the development of new generation antihistamines.

\section{CONGA recommendations}

CONGA recommendations comprise 6 areas:

1. Anti-inflammatory properties: A third-generation antihistamine should possess anti-allergic properties demonstrable in vivo, in humans, at therapeutic doses and under natural exposure to the offending allergens. It should be superior (in humans) to a comparator devoid of such properties. Nasal obstruction should be affected in a measurable way.

2. Potency, efficacy, and effectiveness: The drug should have a high therapeutic index and differ radically from existing compounds.

3. Lack of cardiotoxicity.

4. Drug interactions: A third-generation antihistamine should not affect cytochrome P450 (CYP) isoenzyme function or be affected by it. This new drug should not displace protein bound medication and it should not affect active transportation mechanisms important in drug absorption and excretion.

5. Lack of CNS effects: The minimum factors for classifying an antihistamine as "non-sedative" should include the study of incidence of subjective sleepiness, objective and psychomotor functions, and positron emission tomography (PET) measurement of $\mathrm{H}_{1}$-receptor occupancy.

6. Pharmacological approach: The drug could be either an $\mathrm{H}_{1}$ blocker with an extra effect or a clean blocker of the $\mathrm{H}_{1}$ effects, having a special feature (eg, neutral antagonist).

\section{Ebastine}

Ebastine (4-diphenylmethoxy-1-[3-(4-terbutylbenzoyl) propyl] piperidine, Las-W-90, CAS 90729-43-4) $)^{18,19}$ is a long-acting, second-generation, selective $\mathrm{H}_{1}$-receptor inverse agonist, discovered and developed by Almirall SA. After over 18 years of use in more than 80 countries around the globe, the efficacy and safety of ebastine has been extensively demonstrated. Its clinical indications include the treatment of seasonal ${ }^{20-24}$ and perennial allergic rhinitis ${ }^{25,26}$ and chronic idiopathic urticaria. ${ }^{27,28}$ Small studies have found beneficial effects in patients suffering from allergic dermatitis, cold urticaria, ${ }^{29}$ dermographic urticaria, ${ }^{30}$ atopic asthma, ${ }^{30,31}$ mosquito bites, ${ }^{32}$ and the common cold (in combination with pseudoephedrine). ${ }^{33}$ The pharmacology and the safety and efficacy profile of ebastine have been comprehensively reviewed. ${ }^{18,19,34,35}$ When administered in vivo, at least one of its metabolites, carebastine, also possess anti- $\mathrm{H}_{1}$ activity. ${ }^{36}$

\section{Ebastine according to the CONGA recommendations \\ Anti-inflammatory properties}

The efficacy of $\mathrm{H}_{1}$ antihistamines in allergic disorders has traditionally been attributed to their effects on the 
histamine receptor. ${ }^{8}$ The involvement of histamine in the allergic process has long been known, but as Thurmond et $\mathrm{al}^{37}$ recently suggested, its importance in modulating this reaction may have been underestimated. The allergic cascade is a complex response that is composed of three distinct immunological phases: sensitisation, early-phase allergic reaction and late-phase allergic reaction. ${ }^{38}$ Histamine's role in this cascade comprises several cellular events involving the expression and/or release of cytokines, chemokines, adhesion molecules, and inflammatory mediators. ${ }^{39}$ These inflammatory mediators are modulated by $\mathrm{H}_{1}$ antihistamines, as has been demonstrated both in vitro and in vivo. ${ }^{40}$ While some authors postulate that these effects are independent of the $H_{1}$ receptor, ${ }^{41-43}$ others relate them to $H_{1}$ receptor blockade, ${ }^{44,45}$ although recent evidence has shown that both statements could be true. ${ }^{40}$

$\mathrm{H}_{1}$ receptor-dependent mechanisms involve stabilization of the histamine receptor in its inactive conformation. Consequently, this stabilization inhibits generation of, globin transcription factor 3 (GATA-3), activator protein-1 (AP-1) and nuclear factor $\kappa \mathrm{B}(\mathrm{NF}-\kappa \mathrm{B}){ }^{8,40} \mathrm{AP}-1$ and NF- $\mathrm{KB}$ are important transcription factors in inflammation. They regulate the expression of many pro-inflammatory mediators, such as CCL5/regulated upon transcription normal $\mathrm{T}$ cell expressed and secreted (RANTES), and play an important role in the pathogenesis of chronic inflammatory diseases such as asthma and allergy. Both are activated by the $\mathrm{H}_{1}$ receptor in an agonist-dependent manner, and this activation is inhibited by various $\mathrm{H}_{1}$-receptor antihistamines. ${ }^{40,46}$

$\mathrm{H}_{1}$ receptor-independent mechanisms, however, inhibit histamine release from mast cells and basophils. They also inhibit inflammatory cell activation, and possibly eicosanoid generation and oxygen free radical production. ${ }^{8}$ The inhibition of inflammatory cell activation comprises the downregulation of adhesion molecule expression, mediator release, superoxide generation, chemotaxis and cytokine expression, and the upregulation of the number and function of $\beta 2$ adrenoceptors. The clinical relevance of this effect is still under discussion due to the fact that very high drug concentrations are needed and it is unlikely that these concentrations are achieved with therapeutic doses.

Modulation of adhesion molecule expression is important because molecules, such as inter-cellular adhesion molecule 1 (ICAM-1) influence the activity of eosinophils, mast cells, macrophages and lymphocytes, all of which play key roles in the allergic reaction. ${ }^{8,47}$ This modulating mechanism has been demonstrated in vitro and in vivo. In vitro, it has been shown that antihistamines reduce ICAM-1 expression on nasal and conjunctival epithelial cells, and it has also been observed that they reduce inflammatory infiltration after allergen challenge and during natural exposure. The mechanism underlying modulation of ICAM-1 is downregulation of the $\mathrm{NF}-\kappa \mathrm{B}$ transcription factor (that is necessary for adhesion molecule expression). Roumestan et al demonstrated that second generation $\mathrm{H}_{1}$ receptor antihistamines, mizolastine and desloratadine, inhibit NF- $\mathrm{KB}$ activity via two distinct pathways. One of these involves the $\mathrm{H}_{1}$ receptor (referred to earlier in this article), and the other is independent from this receptor. These authors also provided evidence that azelastine represses AP-1 activity via the same mechanisms. ${ }^{40}$

The inhibition of mediator release is another mechanism whereby antihistamines affect the allergic inflammatory reaction, independently of their anti- $\mathrm{H}_{1}$ activity. In vitro studies have consistently established that $\mathrm{H}_{1}$ antihistamines inhibit the release of mediators from both mast cells and basophils. Nevertheless, these results are difficult to replicate in vivo as 3- or 4-fold therapeutic concentrations of antihistamines would be needed. ${ }^{8}$ As cytokines appear to contribute to the activation of basophils and eosinophils (chiefly interleukins [IL] 4 and 5) and the establishment and maintenance of allergic inflammation, the effect of $\mathrm{H}_{1}$ antihistamines on cytokine secretion has also been studied with myriad compounds.

The inflammatory modulation of ebastine has been reported in various in vitro, and in vivo studies. ${ }^{31,36,48}$ Campbell et $\mathrm{al}^{48}$ performed an in vitro study using dispersed cells obtained from surgically resected nasal polyps. They examined the effects of ebastine and carebastine on the release of leukotrienes C4/D4 [LTC4/D4] and prostaglandin D2 [PGD2]) after stimulation by anti-IgE and the spontaneous release of granulocyte macrophage colony stimulating factor [GM-CSF], tumour necrosis factor- $\alpha$ [TNF- $\alpha]$ and interleukin-8 [IL-8]. In vitro, ebastine and carebastine were shown to block the release of anti-IgE-induced eicosanoids LTC4/D4 and PGD2. Ebastine inhibited release of the two mediators by $30 \%$ at clinically relevant concentrations $\left(\mathrm{IC}_{30}=2.57-9.6 \mu \mathrm{mol} / \mathrm{L}\right)$. Carebastine was less effective $\left(\mathrm{IC}_{30}=8.14 \mu \mathrm{mol} / \mathrm{L}\right)$.

Campbell et $\mathrm{al}^{48}$ also performed a double blind crossover study $(\mathrm{n}=12)$ to compare the effect of ebastine 10 and $20 \mathrm{mg}$ once daily with that of placebo on the release of inflammatory mediators. In vivo, ebastine $20 \mathrm{mg}$ induced an increase in the mean threshold number of pollen grains required to induce a positive response compared with placebo $(P<0.003)$ and ebastine $10 \mathrm{mg}(P<0.02)$. Ebastine was found to decrease the release of GM-CSF in a dose-dependent manner. It did not significantly alter the release of LTC4/D4 and PGD2 
observed in most patients during the nasal provocation test and it did not affect cytokine release.

Regarding the secretion of cytokines, Nori et al evaluated the effect of ebastine on the production of $T$ helper $2\left(T_{h} 2\right)$ type cytokines. Using $\mathrm{T}$ cells derived from healthy non-atopic volunteers, they showed that ebastine inhibited the secretion in vitro of IL-4 and IL-5, but not that of IL-2 and interferon $\gamma(\mathrm{IFN} \gamma){ }^{49}$

Ebastine's role in reducing airway inflammation has been suggested by Horiguchi et $\mathrm{al}^{31}$ who performed an open label study in which 20 patients with bronchial asthma (11 with atopic disease and 9 with nonatopic disease) received ebastine $10 \mathrm{mg} /$ day for 4 weeks. Serum eosinophil cationic protein (ECP) levels, peripheral blood eosinophil counts, morning peak expiratory flow rate (PEFR) and thresholds for airway hyper-responsiveness were determined before and after treatment. As a result, the atopic patients observed a decrease in serum ECP levels (from $25 \pm 3 \mathrm{mg} / \mathrm{L}$ to $16.3 \pm 2.4 \mathrm{mg} / \mathrm{L}$; $P<0.0014)$ and in peripheral blood eosinophil counts (from $468.2 \pm 44.4 / \mathrm{mm}^{3}$ to $417.3 \pm 47.8 / \mathrm{mm}^{3} ; P<0.0253$ ). PEFR was significantly increased in the atopic patients $(410.9 \pm 16.1 \mathrm{~L} / \mathrm{min}$ to $440 \pm 19.1 \mathrm{~L} / \mathrm{min} ; P<0.0189)$. No changes were found in the nonatopic patients and there was no change in the threshold for airway hyper-responsiveness.

The results of another in vivo study by Ciprandi et al have been published recently. ${ }^{50}$ This group evaluated IFN $\gamma$ production by peripheral blood mononuclear cells (PBMNC) using different stimuli in un-treated and treated (ebastine $20 \mathrm{mg}$ ) patients with persistent allergic rhinitis. Clinical changes were assessed by subjective (total nasal symptom score and visual analogue scales [VAS]) and objective (rhinomanometry) evaluations. The main result from this study was that IFN $\gamma$ production stimulated by grasses and Dermatophagoides farinae was statistically increased $(P<0.0001$ and $P<0.0015$ respectively) in patients receiving ebastine.

Nasal obstruction is the leading symptom in patients with allergic rhinitis, with allergic inflammation, mucosal congestion and mucus hypersecretion playing key roles. ${ }^{51} \mathrm{CONGA}$ recommendations suggest that nasal obstruction should be affected in a measurable way by newer antihistamines. The decongestant activity of ebastine was first suggested by Ratner et $\mathrm{al}^{52}$ after they performed 3 double-blind, randomized, placebo-controlled, parallel group studies that compared ebastine $20 \mathrm{mg}$, ebastine $10 \mathrm{mg}$, loratadine $10 \mathrm{mg}$ and placebo in the control of symptoms of ragweed-induced rhinitis. Although the results showed that ebastine at both doses reduced nasal congestion as compared to placebo, nasal congestion was measured subjectively (ie nasal congestion symptom scores). The effect of ebastine on nasal obstruction was further evaluated in a pilot study $(n=20)$ by Ciprandi et al. ${ }^{53}$ These authors evaluated nasal symptoms (rhinorrhea, itching, sneezing and obstruction), nasal airflow (by means of rhinomanometry) and the response to a decongestion test with naphazoline $1 \mathrm{mg} / \mathrm{mL}$ in patients with persistent allergic rhinitis before and after 3 weeks of treatment with ebastine $20 \mathrm{mg} /$ day. Results were positive and showed that ebastine induced symptom relief as assessed by comparing basal nasal symptom total scores with post-treatment scores $(P=0.0013)$. Ebastine also increased nasal airflow $(P=0.0001)$ and in the decongestion test the percentage of reversibility diminished significantly from baseline (111\%) to post ebastine treatment $(46 \%, P=0.0003)$. Although a double-blind, randomized controlled trial with active comparators and placebo would be the most suitable design to obtain conclusive evidence, this pilot study showed that nasal obstruction can be affected in a positive way by antihistamine treatment with ebastine.

Presently available evidence indicates that some second generation antihistamines possess properties that modulate the allergic inflammatory cascade by means of $\mathrm{H}_{1}$ receptor dependent and independent mechanisms. All in all, in vitro, in vivo and clinical studies using subjective and objective measurements seem to indicate that ebastine possesses this characteristic and ameliorates nasal congestion to some degree. However, to clarify this effect a clinical trial including a comparator devoid of modulator effect should be carried out. Until this piece of the puzzle is put in place we can not conclusively claim that ebastine complies with the first requirement exposed in the CONGA. Including more than one comparator in future studies would be especially useful as it would provide further information that could help to elucidate the allergic/ inflammation pathways that each antihistamine involves.

\section{Potency, efficacy, and effectiveness}

Ebastine was initially conceptualized as the combination of the structural elements of the very potent, yet sedative antihistamine, diphenyl-pyraline and the less potent, but nonsedative, terfenadine. ${ }^{16}$

The receptor-binding affinity and receptor-dissociation rate for antihistamines on peripheral $\mathrm{H}_{1}$ receptors help to better characterize novel anti- $\mathrm{H}_{1}$ receptor drugs. They also allow an appraisal of the likely in vitro potency at the $\mathrm{H}_{1}$ receptor in relationship to known standards, and provide potential information on duration of action. ${ }^{54} \mathrm{The}_{1} \mathrm{H}_{1}$ receptor affinities for ebastine and carebastine are $48 \pm 6 \mathrm{nM}$ and 
$27 \pm 4 \mathrm{nM}$, respectively, while two other minor metabolites also have good $\mathrm{H}_{1}$ receptor affinity (HO-ebastine and diphenyl-norpyraline). ${ }^{55}$

The binding characteristics of an $\mathrm{H}_{1}$ receptor antihistamine determine the extent to which histamine can be blocked from binding to the $\mathrm{H}_{1}$ receptor. These binding characteristics are an integral component for the efficacy and safety of an antihistamine. However, specific characteristics of an $\mathrm{H}_{1}$ receptor antihistamine may influence its potency, and high in vitro $\mathrm{H}_{1}$ binding activity does not necessarily imply good clinical efficacy because many other factors (such as uptake, metabolism, and pharmacokinetics) are also relevant. Moreover, some $\mathrm{H}_{1}$ receptor antihistamines may lack specificity and bind to other receptors, causing unwanted side effects. ${ }^{38}$

Ebastine has a potent and selective $\mathrm{H}_{1}$ antihistamine activity, as assessed by in vitro and in vivo studies. Contrary to the properties of other antihistamines, the anticholinergic and anti-serotonergic properties of ebastine have proved to be negligible. ${ }^{56}$ Ebastine and carebastine show a weak affinity for the 5-HT receptor, and they do not bind to adrenergic $\alpha_{1}$, dopaminergic $\mathrm{D}_{2}$, benzodiazepine, muscarinic, cholecystokinin, N-methylD-aspartatic acid (NMDA), calcitonin gene-related peptide (CGRP), neuropeptide $\mathrm{Y}$, neurotensin, opiate, somatostatin, $\mathrm{NK}_{1}$, vasopressin $\mathrm{V}_{1}$, vasoactive intestinal peptide (VIP), bradykinin $\mathrm{B}_{2}$, or $\mathrm{Ca}^{++}$channels. ${ }^{55}$

In vitro potency has been demonstrated in a series of experiments performed by Almirall. Their results showed that ebastine inhibits histamine-induced contractions in an isolated ileum model. In a competitive antagonism assay, they found that the negative logarithm of the concentration $(\mathrm{mol} / \mathrm{L})$ of antagonist which would produce a 2 -fold shift in the concentration-response curve for an $\mathrm{H}_{1}$ agonist $\left(\mathrm{pA}_{2}\right)$ was 7.9 for ebastine and 8.7 for carebastine. ${ }^{36}$ When acetylcholine was used as the agonist, the $\mathrm{ED}_{50}$ value of ebastine was greater than $30 \mathrm{mg}$, sustaining the almost null anticholinergic effect. In a noncompetitive antagonism assay the negative logarithm of the concentration $(\mathrm{mL} / \mathrm{L})$ required to reduce the maximum response to an $\mathrm{H}_{1}$ agonist by half $\left(\mathrm{pD}_{2}\right)$ was 5.8 for ebastine, showing ebastine was at least 100 times less potent as an "atropine-like" muscarinic antagonist than as an antihistamine. ${ }^{36}$ In addition to this isolated ileum model, an in vitro study in tracheally perfused guinea pig lungs provided evidence that ebastine inhibits bronchoconstriction induced by leukotriene $\mathrm{C}_{4}{ }^{56}$

Potency in vivo has mainly been studied in guinea pigs. It has been observed that ebastine causes a dose-related inhibition of histamine-induced bronchospasm with an
$\mathrm{ED}_{50}$ value of $170 \mu \mathrm{g} / \mathrm{kg}$ po ( $80 \mu \mathrm{g} / \mathrm{kg}$ for carebastine) in comparison to terfenadine that required $780 \mu \mathrm{g} / \mathrm{kg} \cdot{ }^{36}$ Llupia et al reported that ebastine had a $\mathrm{ED}_{50} 115 \mu \mathrm{g} / \mathrm{kg}$ po against aerosol histamine-induced bronchospasm in guinea pigs. They also found that ebastine was a potent compound in inhibiting allergen-induced bronchospasm in conscious guinea pigs $\left(\mathrm{ED}_{50} 334 \mu \mathrm{g} / \mathrm{kg}\right.$ po). In another in vivo study, ebastine reversed the changes in pulmonary resistance induced by leukotriene $\mathrm{C}_{4}$ in anesthetized guinea pigs, whereas cetirizine and loratadine were devoid of activity in this model..$^{56}$

Potency in humans can be assessed by evaluating distinct biomarkers that may be related to histamine activity. Examples of biomarkers in this setting are the wheal and flare response after a skin-prick test, the measurement of inflammatory mediators after nasal challenge with histamine or allergens, and the inhibition of histamine-induced brochospasm. ${ }^{54}$

The histamine wheal-and-flare response provides information on the preliminary efficacy of the $\mathrm{H}_{1}$ receptor antihistamine following oral dosing and has been widely used. It is sometimes criticized, however, because it does not mimic the late phase response of the allergic process, mast cell degranulation, and inflammatory mediator release. It has also been stated that it does not correlate with results in patients. ${ }^{38}$ Speed of onset of activity, magnitude of effect and duration of action can be assessed, as with skin-prick test studies, with nasal applications studies, using single-dose histamine challenges at repeated time points.

Ebastine at doses $\geq 10 \mathrm{mg}$ significantly reduced the histamine-induced cutaneous wheal response in healthy adult volunteers and in adult patients with allergic rhinitis in comparison with placebo. ${ }^{19}$ Studies have shown that the reduction in wheal size is significantly greater with ebastine $10 \mathrm{mg}$ than with placebo after intradermal histamine challenge $(P<0.001)$. This reduction reaches its peak around 6 to 12 hours after drug administration. In children, ebastine 5 and $10 \mathrm{mg}$ has shown to reduce histamine-induced wheal and flare compared with baseline values for up to 28 hours. Overall, ebastine $10 \mathrm{mg}$ has shown to be as effective at inhibiting the histamine-induced wheal response as several other antihistamines, whilst ebastine $20 \mathrm{mg}$ proved to be more effective than others (eg, loratadine, cetirizine, and fexofenadine). ${ }^{19,57-59}$

The effect of ebastine has been also assessed by cutaneous and nasal challenge with allergens, and through the measurement of inflammatory mediators. One study aimed to determine the time period required for the inhibitory effect of ebastine on allergen-induced skin reactivity to disappear 
completely, and recruited patients $(n=23)$ with an allergy to house dust mite, cat dander, a mixture of 5 grass pollens, or birch pollen. After 7 days' treatment with ebastine $20 \mathrm{mg}$, skin prick tests with allergens revealed a highly significant $(P<0.01)$ inhibition of the wheal surface area at 6 hours, 24 hours, and 2 days after treatment compared with placebo. The inhibitory effect of ebastine on wheal disappeared by day 4 after discontinuing treatment, and the effect on flare by day 3. A marked inhibitory effect of ebastine was seen on the histamine-induced wheal surface area at 6 and 24 hours after treatment completion compared to placebo. There was no residual effect of ebastine compared to placebo 5 days after treatment discontinuation. ${ }^{19,60}$ Additionally, in grass pollen allergic patients $(n=12)$, van Steekelenburg et al compared 5 second generation antihistamines by assessing eosinophilia in nasal smears, histamine/grass pollen skin tests and grass pollen nasal provocation tests. In patients with grass pollen allergy, ebastine $10 \mathrm{mg}$ reduced the diameter of grass pollen-induced wheals at 4 and 8 hours postdosing to a significantly greater extent than placebo $(P=0.013)$ and to a similar extent to other antihistamines such as loratadine $10 \mathrm{mg}$, cetirizine $10 \mathrm{mg}$, fexofenadine $120 \mathrm{mg}$, and mizolastine $10 \mathrm{mg} \cdot{ }^{19,61}$

The effect on inflammatory mediators has also been tested. As assessed by Campbell et $\mathrm{al}^{48}$ (see section above), mean percent inhibition provoked by ebastine on mediator release from human dispersed nasal polyp cells was $50 \%$ for PGD2, 33\% for LTC4/D4, 40\% for tumor necrosis factor- $\alpha$ (TNF- $\alpha$ ), 35\% for GM-CSF, and $52 \%$ for IL- 8 , compared to placebo (all $P<0.05$ ).

Antonijoan et al performed two double-blind, double-dummy, randomized, placebo-controlled, 3-period crossover clinical trials ${ }^{14,62}$ to assess the pharmacodynamics of a fast-dissolving tablet (FDT) of ebastine. This relatively new formulation facilitates administration to patients who have problems swallowing tablets and hard gelatine capsules, such as geriatric patients and those who are ill in bed or those who may not have access to water to aid swallowing. In these studies ebastine $(10 \mathrm{mg}$ in the first and $20 \mathrm{mg}$ in the second study) was compared with desloratadine $5 \mathrm{mg}$ or placebo. Besides assessing the inhibition of wheal response to cutaneous histamine challenge using a histamine skinprick test, both included subjective assessments of itching, flare and pain by means of VAS, tolerability assessments, as well as acceptability and convenience evaluation, measured by a questionnaire. The main outcome was inhibition of the response to the histamine challenge, defined as the percentage reduction from baseline in the wheal area of the skin intradermal test conducted 24 hours after the fifth dose of study medication.

In the first trial ${ }^{62}$ (FDT ebastine $10 \mathrm{mg}$ ), the mean percentage reduction from baseline in the wheal area 24 hours after completion of 5 days' treatment was significantly greater with ebastine than with desloratadine and placebo (44.6\% vs $17.9 \%$ and $-2.3 \%$, respectively; both $P<0.0001$ ). Mean differences in reduction from baseline to 24 hours after 5 days of treatment in the wheal area were $26 \%$ for FDT ebastine $10 \mathrm{mg}$ vs desloratadine $5 \mathrm{mg}$ and $46.9 \%$ for ebastine vs placebo (both, $P<0.0001$ ). In the second trial ${ }^{14}$ (FDT ebastine $20 \mathrm{mg}$ ), the mean percentage reduction from baseline in wheal area 24 hours after 5 days of treatment was significantly greater with ebastine compared with desloratadine, and placebo (55.8\% vs $26.8 \%$ and $12.2 \%$, respectively; both $P<0.001$ ). Mean differences in reduction from baseline in the wheal area were $29 \%$ for ebastine $20 \mathrm{mg}$ vs desloratadine $5 \mathrm{mg}$, and $43.7 \%$ for ebastine vs placebo (both, $P<0.001$ ).

These studies showed that, after 5 days of administration, inhibition of the response to histamine injection was significantly greater with FDT ebastine 10 and $20 \mathrm{mg}$ than with desloratadine $5 \mathrm{mg}$. As denoted by the authors, this test does not necessarily correlate with clinical responses. However, it is important to assess and compare the pharmacodynamic effects of antihistamines. ${ }^{14,62}$

Concerning the therapeutic index, evidence supports the notion that ebastine has a wide therapeutic index. In pharmacological safety models, ebastine showed no central nervous system effects and did not affect heart rate or blood pressure in conscious rats and dogs at doses up to $100 \mathrm{mg} / \mathrm{kg}$ (ie, 600 times the therapeutic dose). ${ }^{63}$

The toxicology profile also showed that ebastine is free of toxic effects in animals, even at doses representing extremely high multiples of the recommended therapeutic dose in humans $(0.17 \mathrm{mg} / \mathrm{kg}){ }^{36}$ In fact, since the lethal dose $50 \%$ $\left(\mathrm{LD}_{50}\right)$ was impossible to calculate, the therapeutic safety ratio $\left(\mathrm{LD}_{50} / \mathrm{ED}_{50}\right)$ of ebastine is more than $20000 .^{36}$

As well as all of the pharmacodynamic characteristics described above, ebastine has shown to be effective for the relief of symptoms in adults and adolescents with allergic rhinitis or chronic idiopathic urticaria. The efficacy of ebastine for the treatment of seasonal and perennial allergic rhinitis has been evaluated in five pivotal trials ${ }^{20,25,26,64-66}$ and several supporting trials. ${ }^{22,23,67-70}$ Pivotal trials enrolled a total of 1394 patients (685 in the seasonal allergic rhinitis studies and 709 in the perennial allergic rhinitis). Four of the trials lasted 3 weeks and the other lasted 12 weeks. The goal was to show superiority of ebastine over placebo. Ebastine 10 and 
$20 \mathrm{mg}$ were used. The primary goal of the comparative efficacy in supporting studies was to show the superiority of ebastine over other $\mathrm{H}_{1}$ receptor antihistamines. ${ }^{55}$ In most trials, the evaluation of efficacy was based on the assessment of nasal symptoms (rhinorrhea, sneezing, itching and obstruction) and ocular symptoms (eg itch, discharge, conjunctivitis). Symptoms were assessed individually and/or as composite scores such as total symptom score, nasal index (a composite of 4 nasal symptoms) or perennial index (nasal symptoms excluding obstruction). ${ }^{19}$

Overall, ebastine has shown superiority over placebo in the treatment of seasonal and perennial allergic rhinitis and ebastine $10 \mathrm{mg}$ has shown to be at least as effective as loratadine $10 \mathrm{mg}$ and cetirizine $10 \mathrm{mg}$ at reducing symptoms in patients with allergic rhinitis, whereas ebastine $20 \mathrm{mg}$ was generally more effective than the comparator antihistamines at the used dosages. ${ }^{19,55}$ In contrast with the differences detected when using the skin wheal and flare test, few clinical differences were observed among the different antihistamines when the allergic rhinitis model was used. ${ }^{71}$

For chronic idiopathic urticaria, the efficacy of ebastine has been evaluated in 2 randomized, double-blind, controlled trials, one compared to placebo ${ }^{28,72}$ and the other to terfenadine and placebo. ${ }^{28}$ Efficacy evaluations included change from baseline in symptoms and global evaluation of efficacy by patients and physicians. Ebastine $10 \mathrm{mg}$ was significantly more effective than placebo at reducing the symptoms of urticaria $(P<0.001)^{28,72}$ and was similar to terfenadine $60 \mathrm{mg}$ twice daily. ${ }^{28}$

Effectiveness, or $\mathrm{H}_{1}$ antihistamine activity in the real world, as expressed by patients' willingness to use a specific $\mathrm{H}_{1}$ antihistamine, has been extensively studied for the FDT formulation of ebastine. ${ }^{73-78}$ Roger et $\mathrm{al}^{73}$ performed a clinical study in which they assessed qualitative face-to-face interviews with physicians and allergy patients in order to understand the key attributes of the FDT formulation of ebastine (a placebo sample was used). The key attributes were convenience, ease of use, and perception of faster onset of action. Moreover, most patients (75\%) expressed that the FDT formulation would improve compliance, and the likelihood of taking/prescribing this formulation was ranked high both by patients and physicians ( 6 to 8.8 for patients and 7.4 to 8.1 for physicians on a 1 to 10 scale). Ebastine FDT has also been rated better by patients for general assessment, texture, initial taste, after taste and sensation on dissolving. ${ }^{75}$ This has been further proved by a quantitative, descriptive, cross-sectional opinion study in which pharmacists answered a structured questionnaire after evaluating the experience referred by clients who had tried the ebastine FDT formulation. Ebastine FDT was conveniently rated for time to dissolving and sensation on dissolving (4.35 [SD 0.95] and 4.03 [SD 0.92] respectively). ${ }^{78}$

All the above-mentioned characteristics are examples of desirable properties in third-generation antihistamines. Notwithstanding, ebastine does not show a radically different profile from existing compounds that would allow its denomination as a third-generation antihistamine.

\section{Lack of cardiotoxicity}

In the mid 1990s, some second generation $\mathrm{H}_{1}$ antihistamines were associated with prolongation of the QT interval and the development of fatal arrhythmias such as torsade de pointes. ${ }^{79,80}$ Two second-generation antihistamines, terfenadine and astemizole (both now withdrawn from the market), block the rapid component of the delayed rectifier potassium current $\left(\mathrm{IK}_{\mathrm{r}}\right)$. As a result, these drugs potentially prolong the monophasic cardiac action potential and QT interval, induce the development of early after-depolarizations and dispersion of repolarization, and may thereby cause torsade de pointes. ${ }^{39}$ It is noteworthy that these events are mostly associated with high plasma concentrations due to overdose or co-administration with other drugs that inhibit their metabolism via hepatic microsomal enzymes (such as CYP3A4). Moreover, cardiac toxic effects induced by $\mathrm{H}_{1}$ antihistamines are rare as they occur independently of the $\mathrm{H}_{1}$ receptor and are not a class effect. ${ }^{10,39,81}$

The withdrawal of terfenadine and astemizole, along with other drugs that have proven to be cardiotoxic, has brought cardiac safety in the drug development process to the forefront of regulatory medicine. Since 1997, regulatory guidelines have been available, emphasizing the strategy for assessing the propensity of new (nonantiarrhythmic) medicinal products to prolong the QT interval. The first of these was issued by the EU Committee for Proprietary Medicinal Products (CPMP). It included recommendations for the design of clinical and nonclinical testing in order to assess the cardiac safety profile of new chemical entities (NCEs).

In 2002, the US Food and Drug Administration (FDA) and Health Canada (HC) issued a joint preliminary concept paper on clinical strategies for evaluating the effects of NCEs on QT/QTc interval prolongation. This paper was later adopted by the International Conference on Harmonization (ICH) for global implementation as ICH topic E14 and published simultaneously with ICH topic S7B, which is primarily concerned with the nonclinical investigation of the 
effects of new drugs on cardiac repolarization. Approved in 2005, ICH E14 is concerned mainly with the design, conduct, analysis, and interpretation of clinical studies to assess the potential of a drug to delay cardiac repolarization. The main tool proposed to meet this goal is the "thorough QT/QTc study". Design is central to this study as it should be randomized and double-blind, and should involve the concurrent use of both a placebo control group and a positive control group (pharmacological or nonpharmacological) to establish assay sensitivity. Whenever possible this study should be crossover. To address intrinsic variability in the conduct of the thorough QT/QTc study, the collection of multiple electrocardiograms (ECGs) at baseline and during the study is strongly recommended. Moreover, the examination of concentrations that are higher than those achieved following the anticipated therapeutic doses is also deemed necessary. Reliability is further enhanced by digitally obtained ECG recordings, electronic transmission and central collection for measurement. ${ }^{13}$

Ebastine and its main active metabolite, carebastine, have been exhaustively evaluated for potential effects on cardiac repolarization. ${ }^{82}$ Ebastine shares some structural features with terfenadine and it is able to interact with potassium channels. Some years ago this gave rise, to concerns about its possible cardiotoxic effects. Such concerns have now been addressed and discarded following results from experimental models both in animals and in the clinical setting. Ebastine either has no deleterious cardiac effects or shows only small and non-clinically significant effects at this level. One possible explanation for its increased $\mathrm{H}_{1}$ receptor activity and its almost null cardiotoxicity in comparison with terfenadine is that subtle modifications in structure not only make ebastine nonchiral but also determine the acquisition of a folded 3-dimensional conformation, as opposed to the extended conformation of terfenadine. The modifications in structure consist of the replacement of the alcoholic hydroxyl group by a ketone oxygen and the introduction of an ether link between the diphenyl-methyl moiety and the piperidine ring. ${ }^{16,83}$

In vitro, the electrophysiological effects of ebastine and carebastine have been studied in isolated rabbit Purkinje fibers. In normal and low potassium solutions (4 $\mathrm{mM}$ and $2.7 \mathrm{mM} \mathrm{K}^{+}$) ebastine (at a concentration of $1 \mathrm{nM}$ to $1 \mu \mathrm{M}$ ) and carebastine (at a concentration of $1 \mathrm{nM}$ to $1 \mu \mathrm{M}$ ) produced a concentration-dependent prolongation of action potential duration (APD) without impairment of the maximum rate of depolarization. ${ }^{55}$

Ko et $\mathrm{al}^{84}$ performed a study on suppression of potassium channels by ebastine, utilizing the whole cell patch-clamp technique. The $\mathrm{I}_{\mathrm{Kr}}$ channel (delayed rectifying rapid) was examined in both the human Ether-à-go-go Related Gene (HERG)-expressing $\times$ laevis oocytes and guinea pig ventricular myocytes; the $\mathrm{I}_{\mathrm{Ks}}$ (delayed rectifying low) and the $\mathrm{I}_{\mathrm{K} 1}$ (inward rectifying) were studied in the guinea pig ventricular myocytes and the $\mathrm{I}_{\text {to }}$ (transient outward) and the $\mathrm{I}_{\mathrm{Kped}}$ (rapidly activating delayed rectifier) were studied in the rat heart. This study showed that ebastine had significant suppressive effects on the $\mathrm{I}_{\mathrm{Kr}}, \mathrm{I}_{\mathrm{Ks}}$ and $\mathrm{I}_{\mathrm{Kped}}$ channels, but it was less effective in blocking the $\mathrm{I}_{\text {to }}$ and $\mathrm{I}_{\mathrm{Kl}}$. These results have been challenged in the past for quoting values for $50 \%$ inhibition of the maximum inhibition and not $50 \%$ of complete inhibition. ${ }^{55}$

Almirall performed studies transferring hERG channels to human embryonic kidney (HEK-293) cells. They compared ebastine to terfenadine and loratadine and calculated the $\mathrm{IC}_{50}$. The results were $331 \mathrm{nM}$ for ebastine, $208 \mathrm{nM}$ for terfenadine and $200 \mathrm{nM}$ for loratadine. With these data they concluded that ebastine is the least likely of the antihistamines tested to affect hERG channels. ${ }^{55}$

In vivo animal evidence concerning the effect of ebastine on cardiac conduction was controversial for many years. One of the in vivo models used to assess ebastine effects was the corrected QT (QTc) interval prolongation following drug administration to anesthetized guinea pigs. ${ }^{85}$ Hey et $\mathrm{al}^{86-89}$ (working for Schering-Plough Research Inc., US marketer of loratadine) showed that intravenously administered ebastine ( 3 to $50 \mathrm{mg} / \mathrm{kg}$ ) caused dose-related prolongation of QTc in anesthetized guinea pigs in a manner comparable to that seen with terfenadine ( 1 to $10 \mathrm{mg} / \mathrm{kg}$ ). This group also showed accentuation of QTc prolongation by ebastine (10 mg po, approximately $20 \mathrm{mg} / \mathrm{kg}$ ) in conscious guinea pigs pretreated with ketoconazole (200 mg po, approximately $400 \mathrm{mg} / \mathrm{kg}$ ). Gras et al ${ }^{90,91}$ (employees at Almirall, marketer of ebastine) provided contradictory evidence of the dose-related prolongation of QTc. Ebastine showed no significant prolonging effect on the QTc interval, even when administered at a dose almost 120 times higher than the corresponding dose of terfenadine. In another study the same group found no interaction between ebastine (20 mg po) and ketoconazole (400 mg/kg) administered to conscious guinea pigs, although it should be pointed out that the positive control, terfenadine, was also negative. ${ }^{55}$

In anesthetized dogs intracoronary infusion of ebastine (30 $\mu \mathrm{g} / \mathrm{min}$ for 1 hour) was not associated with an increase in electrocardiographic QTc intervals that predisposed to ventricular arrhythmias..$^{36,82}$

In another in vivo study in rats differences in accumulation of antihistamines into cardiac tissue were addressed. 
Animals were administered antihistamines orally for 5 days at a dose calculated to achieve steady state concentrations substantially higher than in humans. The authors determined the ratio between the $\mathrm{hERG} \mathrm{IC}_{50}$ and the plasma level of the free compound at steady state $\mathrm{C}_{\max }(\mu \mathrm{M})$ and the ratio between the hERG $\mathrm{IC}_{50}$ and the $\mathrm{C}_{\max }$ in the rat heart at steady state. High ratios of ebastine and carebastine suggested that the putative arrhythmogenic potential of ebastine was lower than that of terfenadine. ${ }^{55}$

From the clinical point of view, the cardiac safety of ebastine has been evaluated in several studies. While some of them were specifically designed for this purpose, some others were pharmacokinetic-pharmacodynamic drug interaction studies. Additionally, placebo-controlled efficacy studies, comparative efficacy studies, and studies in special populations have been performed.

Several cardiac safety studies have been conducted. Firstly, Gillen et a $1^{92}$ performed a 4-way crossover study to compare the effect of high doses of ebastine with terfenadine and placebo on QTc. Three and 5-fold the maximum recommended dose of ebastine (ie, 60 and $100 \mathrm{mg}$, once daily) and three-fold the maximum recommended dose of terfenadine (ie, $180 \mathrm{mg}$ bid) or placebo were administered for 7 days. QT was corrected following both the Bazett and Friedericia corrections. According to the results of this trial, ebastine $60 \mathrm{mg}$ did not significantly alter any QTc, vs placebo. Nevertheless, ebastine $100 \mathrm{mg}$ produced a statistically significant prolongation of QTc according to Bazett's correction. In any case, the QTc increase after ebastine $100 \mathrm{mg}$ was significantly less than with terfenadine $(+10.3 \mathrm{~ms}$ vs $+18.0 \mathrm{~ms}, P<0.05)$. Noteworthy is that the authors interpreted that they "overcorrected" the QT interval using Bazett's correction. Since then, Malik ${ }^{93}$ has argued that measuring imprecision and natural variability can lead to mean QTc interval changes of 4 to $5 \mathrm{msec}$ in the absence of drug treatment. He also stated that use of published heart rate correction formulas in the assessment of drug-induced QTc prolongation is inappropriate and that correction formulas optimized for pooled drug-free data are inferior to the formulas individualized for each subject. ${ }^{93}$

Later, a randomized, double-blind, placebo controlled parallel group study compared the electrocardiographic effect of ebastine 10, 20, 40 (in one randomization schedule) and $80 \mathrm{mg}$ qd (in a second randomization schedule) with placebo for 9 days in healthy volunteers. The relationship between QTc prolongation and plasma ebastine/carebastine concentrations was also explored. Primary analysis comprised the change from baseline QTc measurements, according to Bazett's method. In this study, ebastine 10, 20, and $40 \mathrm{mg}$ caused a dose-dependent prolongation of QTc, corrected by Bazett's or Friedericia's formulae. As individual QT variation was very large, no post-hoc analyses of QTc by other methodology could be carried out. ${ }^{55}$

In another attempt to explore the relationship between QTc prolongation and ebastine administration, an open-label, placebo-controlled, single ascending dose study was performed with doses of $80,150,300$, and $500 \mathrm{mg}$ in 6 healthy male volunteers. Increases in heart rate and QTc, corrected by Bazett's or Friedericia's method, were dose-proportional, but no single QTc interval was greater than $500 \mathrm{msec}$, and no intra-individual postdose increase in the mean QTc interval was greater than $10 \%$. The interpretation of these results was limited by the reduced sample size number. ${ }^{55,94}$

Various drug-interaction cardiac safety studies have been carried out. Chiefly, the risk of interaction between ebastine and erythromycin ( 2 studies) or ketoconazole (3 studies) has been evaluated. ${ }^{82,95}$ Two additional studies were aimed at comparing the interaction of loratadine and ketoconazole with the interaction of ebastine and ketoconazole. ${ }^{55}$

One study $(\mathrm{n}=15)$ comprised multiple-dose administration of erythromycin stearate $500 \mathrm{mg}$ every 6 hours on days 4 through 12 with single-dose ebastine $20 \mathrm{mg}$ in the morning of days 1 and 9. Holter monitoring and telemetry showed no clinically relevant changes in QTc interval or cardiac parameters in spite of evident pharmacokinetic interaction between ebastine and erythromycin..$^{55}$ Nonetheless, in a separate crossover study $(\mathrm{n}=30)$, the co-administration of multiple-dose ebastine $20 \mathrm{mg}$ qd with erythromycin ethylsuccinate $800 \mathrm{mg}$ tid for 10 days produced a statistically significant prolongation of QTc interval (10 ms); no clinically significant changes occurred, however. ${ }^{82}$ In comparison to the $\mathrm{C}_{\max }$ and $\mathrm{AUC}_{0-24}$ achieved with ebastine plus placebo, when ebastine plus erythromycin was administered there was a 2-fold increase in the $\mathrm{C}_{\max }$ and a 3-fold increase in the $\mathrm{AUC}_{0-24}$ of ebastine. Additionally there was a 2-fold increase in the $\mathrm{C}_{\max }$ and 2.5-fold increase in the $\mathrm{AUC}_{0-24}$ of carebastine. After treatment, the difference for ebastine plus erythromycin over placebo plus erythromycin for QTc according to Bazett's correction (QTcB) was $10.7 \mathrm{msec}$. The uncorrected comparison was $-2.8 \mathrm{msec}$. Post-hoc analyses did not change overall findings. ${ }^{55,82}$

Assessment of the interaction of a single dose of ebastine $20 \mathrm{mg}$ combined with multiple doses of ketoconazole $400 \mathrm{mg}$ qd on days 4 through $12(\mathrm{n}=12)$ produced no clinically relevant changes in cardiac parameters in healthy male volunteers. ${ }^{55,82}$ 
In a blinded, parallel group, placebo-controlled multiple dose study ( $\mathrm{n}=55$ ), ebastine $20 \mathrm{mg}$ qd or placebo were administered for 5 days and ketoconazole $400 \mathrm{mg}$ qd was added to that treatment for an additional 8 days. In the ebastine plus ketoconazole group the maximum plasma concentrations $\left(\mathrm{C}_{\max }\right)$ of ebastine were 15-fold higher than placebo, the minimum plasma concentrations $\left(\mathrm{C}_{\text {min }}\right)$ were 70 -fold higher and the area under the plasma concentration-time curve $\left(\mathrm{AUC}_{0-24}\right)$ was 40 -fold higher. ${ }^{55,82}$ Initial analysis showed that the addition of 8 days of ketoconazole to ebastine at a steady state caused a $18.1 \pm 2.5 \mathrm{msec}$ prolongation in the mean QTcB compared to an $8.0 \pm 2.3 \mathrm{msec}$ prolongation for the placebo plus ketoconazole combination $(P<0.0023)$. Post-hoc analyses with other QTc correction formulae (Friedericia, Malik and linear regression analysis) did not sizably modify results. ${ }^{55}$ Data were later analyzed correcting QT for heart rate $(\mathrm{QTc})$ using the parabolic $\log / \log$ formula $\left(\mathrm{QTc}=\mathrm{QT} / \mathrm{RR}^{\alpha} ; \alpha=0.25\right.$ for Kawataki, 0.31 for Yoshinaga, 0.32 for Simonson, 0.33 for Fridericia, 0.38 for Hodges, 0.398 for Boudolas, 0.5 for Bazett and 0.603 for Mayeda), but individualized $\alpha$ values derived from individual off-drug QT/RR relationships were used for each subject. Chaikin et $\mathrm{al}^{95}$ argued that this avoids the problem of using formulae based on populations other than that under study, and allows for considerable interindividual variability in QT/RR relationships, but intraindividual variability over time is low. Using this approach, no changes in cardiac repolarization were evidenced by the absence of statistically significant changes in the increase of the mean QTc in the ketoconazole/placebo group (6.96 [95\% CI 3.31 to 10.62$] \mathrm{ms}$ ) compared with ketoconazole/ebastine (12.21 [95\% CI 7.39 to 17.03] ms; $P=0.08) .{ }^{95}$

A pivotal drug interaction cardiac safety study was designed with the input of the FDA and was the first of its kind to include women. ${ }^{55}$ An individual QT correction factor was determined at baseline and used throughout the study. This methodology was deemed satisfactory considering the high inter and intra-individual variability of QT. This multiple dose ebastine and ketoconazole interaction study had a 2-period crossover design. Ebastine $20 \mathrm{mg}$ q.d. was administered for 13 days and ketoconazole $400 \mathrm{mg}$ qd or placebo was added on the last 8 days. The addition of ketoconazole caused a significant increase of 16 -fold in $\mathrm{C}_{\max }$, 44-fold in $\mathrm{AUC}_{0-23.5}$ and 52-fold $\mathrm{AUC}_{0-\infty}$ of ebastine. For carebastine, only the $\mathrm{AUC}_{0-\infty}$ was significantly increased. Ketoconazole increased the resting heart rate on day 13 by $4.6 \mathrm{msec}$ over baseline compared to placebo and provoked a statistically significant $(+11.9 \mathrm{~ms}$ vs $0.38 \mathrm{msec}$ mean QTc; difference $10.71 \mathrm{msec} ; P=0.0000)$ interval prolongation compared to placebo (using Malik correction formula [QTcM]). This held true when using other correction formulae. Using pharmacokinetic/pharmacodynamic regression analysis, it was demonstrated that there was a plateau effect for prolongation of QTc at $10.71 \mathrm{msec}$. This suggests that if exposure increased above that observed in this study, the QTc would not be further prolonged. The FDA later challenged these results and considered that goodness of fit analysis did not support a single exposure-response QTc model due to the limitations inherent to inter- and intra-subject variability.

Results from studies comparing ebastine plus ketoconazole with loratadine plus ketoconazole pointed in the same direction. The mean QTcB change with the administration of ketoconazole was 16.5 for ebastine and 11.3 for loratadine in the first study. In the second study the mean QTcB change was 16.3 for ebastine and 9.6 for loratadine. Differences were of lesser magnitude using Marek Malik's correction. ${ }^{55}$

Pooled data from high-dose ebastine studies and drug interaction studies, particularly studies investigating the interaction between ebastine and ketoconazole, showed a positive relationship between increasing ebastine plasma concentrations and QTc interval changes. In contrast with findings using terfenadine, the QTc interval-plasma concentration curve reached a plateau at low level of QTc prolongation $(10 \mathrm{msec})$ despite large, progressive increases in blood concentrations of ebastine and carebastine..$^{82,96}$

During the placebo-controlled efficacy studies, ECGs were performed at baseline and weekly, at 3 to 5 hours after dosing (around the approximated $\mathrm{T}_{\text {max }}$ for ebastine). Baseline and double-blind ECG evaluations were performed in a total of 1202 patients. Moreover, Holter monitoring was performed in a subset of patients in these studies $(n=226)$. A dosedependent increase of QTc outliers was seen, suggesting that ebastine prolonged QTc in some patients, although no clinically relevant changes were seen on Holter monitoring. ${ }^{55}$ As opposed to placebo-controlled studies, comparative efficacy studies did not include Holter monitoring. With the exception of a few outliers, no definitive statements about cardiac safety could be made. ${ }^{55}$

The pharmacokinetics of ebastine have been investigated in several special situations. Evidence has emerged from a food interaction study, and from studies in patients with renal failure ${ }^{97}$ and liver failure, ${ }^{98}$ and in children ${ }^{82}$ and elderly volunteers. In the food interaction study a single dose of ebastine 10 or $20 \mathrm{mg}$ with and without food produced no clinically relevant electrocardiographic effects, despite the fact that exposure to carebastine was $50 \%$ higher with food than without. ${ }^{82}$ No clinically relevant ECG findings have been observed 
in patients with renal failure, ${ }^{97}$ liver failure, ${ }^{98}$ or children. ${ }^{82}$ The electrocardiographic effect of ebastine in the clinical setting was studied by Huang et al. ${ }^{99}$ These authors performed a randomized, double-blind, multiple-dose, placebo-controlled, parallel group study in healthy young and elderly volunteers. Twelve-lead electrocardiography was performed before dosing and repeated 4 hours after dosing on days 1, 5, and 10 . Additionally, 24-hour Holter monitoring was performed after 10 days of treatment with ebastine $10 \mathrm{mg}$ or placebo. The results showed no clinically significant abnormalities either in young or in elderly volunteers.

Undoubtedly, the most difficult and contentious issue facing ebastine has been proving its cardiac safety. Ebastine was first marketed in Spain in 1990 and in 1998 the first New Drug Application (NDA) submission was filed by Rhône-Poulenc Rorer, Almirall's strategic partner at that time. Because of cardiac safety concerns and significant pharmacokinetic interactions with drugs metabolized by CYP3A4 that resulted in increased plasma concentrations and potential QTc interval prolongation, the FDA decided not to approve ebastine for marketing in the US on March 23, 1999. ${ }^{55}$ Three years later, in 2002, Almirall resubmitted an NDA for ebastine. They provided new clinical evidence of its safety and argued that Bazett's method for QT correction tended to overcorrect the QTc interval when heart rate is increased. Ebastine's cardiac safety has been assessed differently by different regulatory bodies around the globe. Ebastine is currently marketed in over 80 countries and there have been no reports of fatal arrhythmias linked to its use. Nevertheless, caution is warranted in patients with a long QT interval, in those who are on drugs that affect the P450 cytochrome system, and in patients with hypokalemia.

In retrospection, a thorough QT/QTc study with a concurrent positive control would have provided valuable information on the cardiac safety of ebastine and would possibly have eliminated the need for further studies. No such study was performed for ebastine as guidelines for QT/ QTc studies were not published until 2005. A thorough QT/QTc study provides very reliable information, as the subjects serve as their own controls and hence reduce differences related to inter-subject variability. In addition, the thorough QT/QTc study design facilitates heart rate correction approaches based on individual subject data. ${ }^{13}$

\section{Drug interactions}

The interactions described to date between $\mathrm{H}_{1}$ antihistamines and other drugs or substances fundamentally take place via three different routes: the P450 cytochrome system
(CYP450), P glycoprotein (PgP), and the members of the organic anion transport polypeptide (OATP) family. ${ }^{100}$ Other possibilities include displacement of a protein bound drug fraction. The most relevant and hence the most thoroughly studied of these have been those involving CYP450.

Given the previous background, studies to assess potential pharmacological drug interactions for new antihistamines comprise at least 2 general axes: interactions that could impair cardiac safety, mainly as a consequence of a pharmacokinetic interaction at the metabolic level, and interactions that could impair CNS safety, mainly as a consequence of a pharmacodynamic interaction with recognized CNS depressants.

The metabolism of ebastine to carebastine was demonstrated in rat small intestine and liver tissue. ${ }^{101}$ Ebastine undergoes extensive metabolism to form desalkylebastine and hydroxyebastine. ${ }^{102-104}$ Hydroxyebastine is subsequently metabolized to carebastine. Until recently, the specific hepatic CYP450 enzymes involved in these processes had eluded us. However, utilizing chemical inhibition and kinetic analysis studies in human liver microsomes, Liu et al ${ }^{104}$ concluded that dealkylation of ebastine and its metabolites is mainly catalyzed by CYP3A4, and CYP3A5 to a lesser degree. Moreover, hydroxylation reactions are preferentially catalyzed by CYP2J2. Thus, when a therapeutic dose of ebastine is given together with therapeutic doses of other drugs metabolized by CYP3A4, a pharmacokinetic interaction can occur, usually producing increases in ebastine plasma concentrations. This interaction is associated with the possible prolongation of the QTc interval. Whether this prolongation occurs or not has been subject to debate, as discussed in the previous section. Nevertheless, even if it is present, it does not seem to be clinically relevant.

CYP3A4 inhibitors such as cimetidine, clarithromycin, clotrimazole, erythromycin, fluoxetine, gestodene and ketoconazole could increase the risk of toxic concentrations of substances such as ebastine that are metabolized via the CYP3A4 pathway. ${ }^{100}$ To date ebastine has been investigated in drug interaction studies with ketoconazole, erythromycin and cimetidine. The first two of these studies were reviewed in a previous section of this manuscript.

Van Rooij et al ${ }^{105}$ studied the influence of cimetidine in the metabolism of ebastine. They conducted a doubleblind, placebo-controlled, randomized, crossover study in which 12 volunteers were administered a single dose of ebastine $20 \mathrm{mg}$ on day 2 of a multiple administration of cimetidine (400 mg tid and $800 \mathrm{mg}$ in the evening on the day preceding ebastine administration and $400 \mathrm{mg} 4$ times 
daily on the following 2 days) or placebo. Blood samples for determination of ebastine and carebastine were taken over the course of the last 2 days. Ebastine concentrations were only detected in 1 subject and were negligible. The authors detected no significant effect of cimetidine on the conversion of ebastine to carebastine or on carebastine kinetics $\left(\mathrm{AUC}_{0-\infty}=4049 \pm 985 \mathrm{ng} * \mathrm{~h} / \mathrm{mL}\right.$ after cimetidine vs $3795 \pm 959 \mathrm{ng} * \mathrm{~h} / \mathrm{mL}$ after placebo; 95\% CI of the difference: -412 to 919$)$. Furthermore, they did not find a significant effect on blood pressure or heart rate and sedation was not observed.

Based on the analysis of a series of patients receiving therapeutic anticoagulation, Garcia-Vallejo et al ${ }^{106}$ suggested that ebastine, loratadine and cetirizine showed similar pharmacokinetic interactions when combined with acenocoumarol, perhaps due to hepatic enzymatic induction. Nevertheless, they also stated that this interaction did not result in a high rate of alterations in the international normalized ratio (INR) values or hemorrhagic events, and they concluded that ebastine can be safely administered in patients receiving oral anticoagulation. Besides acenocoumarol, drug interaction studies of ebastine $20 \mathrm{mg}$ with theophylline or warfarin have also been performed and no interactions have been reported. ${ }^{55}$

Mattila et al did not detect any pharmacokinetic interactions between ebastine and ethanol or diazepam in healthy subjects. ${ }^{107,108}$ They performed 2 double-blind, crossover studies in which ebastine $20 \mathrm{mg}$ and placebo were each administered for 1 week. On day 6, drug effects were assessed and on day 7 of both periods, ethyl alcohol $0.8 \mathrm{~g} / \mathrm{kg}$ or diazepam $15 \mathrm{mg}$ were given. No pharmacokinetic interactions were observed, meaning that no change in ebastine, ethanol, or diazepam plasma levels was observed. Pharmacodynamic results (CNS effects) will be discussed in the following section (lack of CNS effects).

It is of note that some drugs (eg, azithromycin, cimetidine, digoxin, erythromycin, fluoxetine, or ketoconazole) that act as substrates or modulators of $\mathrm{PgP}$ activity also act similarly in relation to CYP3A4 and OATP. ${ }^{100}$ Certain $\mathrm{H}_{1}$ antihistamines are $\mathrm{PgP}$ substrates (eg, fexofenadine, loratadine) and, as such, their bioavailability and clearance can be compromised, resulting in higher concentrations of antihistamine. However, drugs that are able to induce PgP yield a lesser concentration of the antihistamine when co-administered and this interaction would therefore result in a decrease in antihistamine efficacy. For ebastine, its metabolite carebastine has been shown to be a substrate of PgP-mediated efflux from the brain at the blood-brain barrier, and a second efflux system is also possibly involved. The relatively low affinity of the uptake transport system for carebastine limits the brain distribution of ebastine/carebastine. ${ }^{109}$

Lastly, both ebastine and carebastine are highly proteinbound (98\%) in the circulation, but the volume of distribution has been reported to be between 90 and 140 L. ${ }^{35}$ Given this combination of factors, protein plasma binding displacement drug interactions are of little concern.

Drug interactions after co-administration of ebastine with a number of other drugs (CYP3A4 inhibitors or drugs with sedative effects) have been correctly investigated. According to the results of clinical trials performed to date, there seems to be no danger of clinically relevant drug interactions in terms of either cardiac or CNS safety. Nevertheless, to be classified as a third-generation compound, it is desirable that a new antihistamine has no drug interactions at all.

\section{Lack of CNS effects}

One of the major disadvantages of first-generation antihistamines is the sedation they cause. This not only limits their use but can also cause accidents while driving and working, and contribute to a decline in productivity and learning efficiency. ${ }^{110-113}$ However this unwanted CNS effect seems to develop tolerance, that is, to dissipate after 4 to 7 days of regular therapy. Sedation induced by these first-generation antihistamines is provoked by their penetration through the blood-brain barrier and consequent occupation of brain $\mathrm{H}_{1}$ receptors. ${ }^{114}$ Thus, the main challenge facing secondgeneration antihistamines has been to block passage through the blood-brain barrier. ${ }^{115}$

Preclinical and clinical data indicate that ebastine has no sedative effect. ${ }^{116}$ The potency and potential CNS effects of ebastine have been studied by means of competition binding and functional assays. In vitro, both ebastine and carebastine have shown a high affinity for the $\mathrm{H}_{1}$ receptor in the guinea pig cerebellum. Furthermore, they inhibit $\left[{ }^{3} \mathrm{H}\right]$-mepyramine binding with a $\mathrm{Ki}$ of $7.1 \mathrm{nM}$ and $7.9 \mathrm{nM}$, respectively. This effect is twice as potent as that shown by terfenadine $(\mathrm{Ki}=14.3 \mathrm{nM})$, but less potent than that seen with astemizole $(\mathrm{Ki}=1.7 \mathrm{nM})$. In experiments measuring inhibition of $\left[{ }^{3} \mathrm{H}\right]$-mepyramine binding to rat cerebral cortex histamine $\mathrm{H}_{1}$ receptors in vitro, the concentration of drug required to inhibit binding by $50 \%\left(\mathrm{IC}_{50}\right)$ was $0.32 \mu \mathrm{mol} / \mathrm{L}$ for ebastine and $0.17 \mu \mathrm{mol} / \mathrm{L}$ for carebastine. These values, similar to those for other second-generation antihistamines, indicate 20 to 40 times less affinity for cerebral $\mathrm{H}_{1}$ receptors than the firstgeneration drug chlorpheniramine $\left(\mathrm{IC}_{50} 0.01 \mu \mathrm{mol} / \mathrm{L}\right) .{ }^{36}$ 
In vivo, the oral dose required to cause $50 \%$ inhibition of $\left[{ }^{3} \mathrm{H}\right]$-mepyramine binding to cerebral $\mathrm{H}_{1}$ receptors $\left(\mathrm{ID}_{50}\right.$ value $)$ was $10.3 \mathrm{mg} / \mathrm{kg}$, indicating that ebastine is more than 500 times less active than chlorpheniramine $(0.02 \mathrm{mg} / \mathrm{kg})$. This emphasizes the fact that it does not easily cross the blood-brain barrier and supports its categorization as a nonsedating antihistamine. ${ }^{36}$

By comparing in vivo cerebral binding data and in vivo peripheral pharmacological data, it is possible to quantify the sedation potential of a given antihistamine. Different studies have shown that the $\mathrm{ID}_{50}$ value for in vivo inhibition of $\left[{ }^{3} \mathrm{H}\right]$-mepyramine binding in mouse cortex is $25.6 \mathrm{mg} / \mathrm{kg}$ and the $\mathrm{ED}_{50}$ value for histamine-induced dermal lesions in mice $\mathrm{H}_{1}$ receptors is $0.09 \mathrm{mg} / \mathrm{kg}$. These values indicate the calculated sedation potential is 0.0035 , as opposed to 0.066 and 555 for terfenadine and d-chlorpheniramine respectively. ${ }^{36}$

CNS penetration has been extensively studied. As ebastine is rapidly metabolized to carebastine, we will focus on this metabolite. First, carebastine's polarity makes it more difficult to penetrate the CNS than ebastine. ${ }^{117}$ Secondly, carebastine does not occupy brain $\mathrm{H}_{1}$ receptors in parallel with increasing plasma carebastine concentration, possibly because carebastine is a substrate of $\mathrm{P}$-glycoprotein and other transporters expressed on the blood-brain barrier, which serve as efflux pumps from the brain to the blood. ${ }^{109}$ Using the BUI (brain uptake index) method in rats, the efflux of [14C] carebastine by the transporters was not inhibited by a large amount of nonlabelled carebastine $(150 \mu \mathrm{M})$ which was about 650 times the plasma concentration obtained from a phase I clinical trial. ${ }^{118}$ This means that although it is theoretically a saturable system, in practice it is not saturated. Ebastine would therefore cause little sedation even when associated with a high plasma carebastine concentration as a result of overdosing or metabolic inhibition. ${ }^{119}$

In clinical trials the most common adverse effects experienced by patients after administration of ebastine have been headache and somnolence, though these effects have not been able to be differentiated from placebo. ${ }^{34}$ Besides this field evidence, information from experimental studies in healthy volunteers specifically performed to assess possible CNS effects is available.

At least 4 studies have been performed to assess the CNS effects of ebastine in laboratory conditions. Psychomotor tests, VAS, and pharmaco-EEG have been used to test the drug against placebo and/or positive comparators (ie, vera). Additionally, a car driving performance study has been carried out in real traffic conditions, comparing ebastine with placebo and a positive comparator. Interactions with ethanol and diazepam and the resulting effect on psychomotor performance have also been evaluated. Finally, central $\mathrm{H}_{1}$ receptor occupancy has been quantified by means of PET scans. Even if all these studies have been performed in healthy volunteers, their value as useful biomarkers of what happens in the clinical scenario is well known.

In a single blind, cross-over, placebo controlled study $(\mathrm{n}=9)$, Vincent et $\mathrm{al}^{116}$ assessed the effects of $10 \mathrm{mg}$ and $50 \mathrm{mg}$ of ebastine on cardiovascular, autonomic and psychomotor function in healthy subjects. Evaluation was performed by means of psychomotor tests, both subjective (such as VAS for sedation and categorical questioning on mood) and objective (critical flicker fusion threshold, choice reaction time and recognition time). Autonomic tests measuring blood pressure, heart rate, salivary secretion and the standing to lying ratio have also been conducted. Besides no effect on blood pressure or heart rate, or any evidence of anticholinergic activity, ebastine did not impair psychomotor performance as assessed by the critical flicker fusion threshold. However, there was a marginal effect on the overall choice reaction time; this was most apparent at the higher dose and its clinical significance remains doubtful. Moreover, ebastine $10 \mathrm{mg}$ had no effect on sedation, although ebastine $50 \mathrm{mg}$ caused a modest increase in indices of sedation $(P<0.05)$.

CNS effects in healthy male volunteers were also explored by Hopes et $\mathrm{al}^{120}$ in a double blind, placebo-controlled trial with a latin square design $(n=16)$. Single doses of ebastine 10 and $20 \mathrm{mg}$ were compared to placebo and to clemastine, a $\mathrm{H}_{1}$ receptor antihistamine that is reported to affect visualmotor coordination and reaction time, and to cause subjective tiredness. The most relevant aspects of behaviour were evaluated: vigilance as measured by quantitative pharmaco-EEG, cognitive performance, visual motor coordination and subjective estimates of sedation. While clemastine produced impairment of psychomotor performance, drowsiness, a selective effect on cognitive processes and a general decrease in vigilance, ebastine did not differ at any time from placebo. Moreover, ebastine also differed positively from clemastine in the EEG features of vigilance (eg, a smaller increase in relative delta ${ }^{\mathrm{F}}$ power $[P<0.05]$ and a smaller decrease in the relative power of the alpha ${ }_{1}$ frequency band) and concerning its effect on pursuit tracking and subjective rating of drowsiness and general discomfort.

Hindmarch et al ${ }^{121}$ performed a double-blind, randomized, 5-period, cross-over study to evaluate the cognitive and psychomotor effects of ebastine $(10,20$, and $30 \mathrm{mg})$ compared with sustained-release triprolidine $(10 \mathrm{mg})$ and placebo in healthy volunteers $(n=10)$. Following each dose, the 
subjects had to perform a battery of tests that comprised the critical flicker fusion threshold, choice reaction time, the simulated car tracking task, Sternberg memory scanning task, assessment of subjective sedation, and subjective evaluation of sleep by means of the Leeds Sleep Evaluation Questionnaire. Triprolidine produced an overall increase of the peripheral reaction time component of the simulated car tracking task, a clear decrement on the Sternberg memory scanning task in comparison to placebo $(P<0.05)$, and significantly greater subjective reports of sedation when compared with placebo $(P<0.05)$. Ebastine was found to be free of impairment on objective aspects of psychomotor and cognitive function.

Tagawa et al ${ }^{122}$ performed another single-blind, randomized, cross-over study to evaluate the effect of ebastine $10 \mathrm{mg}$ on cognitive performance compared to $(+)$ chlorpheniramine $2 \mathrm{mg}$ and $6 \mathrm{mg}$ and placebo. Several attention demanding cognitive tasks (visual discrimination time task [VDT], choice reaction time task [CRT] and simple reaction time task [SRT]) were performed by healthy volunteers $(n=24)$ at the moment when the plasma drug concentration was expected to be at its maximum value. Ebastine was found not to affect task performance or subjective sleepiness, while (+) chlorpheniramine 2 and $6 \mathrm{mg}$ caused concentration-related impairment of task performance (eg, ratios of after/before dosing: placebo [0.998 \pm 0.113$]$ vs $(+)$ chlorpheniramine $2 \mathrm{mg}[1.103 \pm 0.083 ; P<0.05]$ or $(+)$ chlorpheniramine $6 \mathrm{mg}$ $[1.170 \pm 0.139 ; P<0.001]$ in a $7 \mathrm{msec}$ visual discrimination time task. Feelings of sleepiness in the chlorpheniramine groups also increased compared with the placebo group (placebo vs (+) chlorpheniramine 2 and $6 \mathrm{mg}: P<0.05$ ).

Brookhuis et al ${ }^{123}$ performed a double-blind, placebocontrolled trial with triprolidine $10 \mathrm{mg}$ as an active control. They tested ebastine 10,20, and $30 \mathrm{mg}$ on several parameters of driving performance in real traffic in healthy volunteers. Driving performance was tested on day 1 and after a 5-day treatment. As expected, triprolidine $10 \mathrm{mg}$ significantly increased the amount of weaving and the delay in following speed maneuvres of a leading car, compared to placebo, whereas ebastine did not produce any significant change at any dose.

Clinically significant drug interactions can occur when 2 or more drugs are taken in combination. ${ }^{124}$ With antihistamines being among the most widely prescribed medications in the world, and as result of their widespread over-the-counter availability, a large number of ambulant patients using antihistamines could also concomitantly take other drugs. Consequently, understanding drug-drug interaction issues associated with antihistamines is a pertinent topic. ${ }^{125} \mathrm{~A}$ relevant pharmacodynamic drug interaction is one that consists of additive CNS depression effects. In terms of CNS safety, newer-generation agents have improved profiles over first-generation agents. ${ }^{126,127}$ However, even the minimal potential of a drug to produce sedation could be important, since this sedative effect can be further worsened by other CNS depressant drugs, such as antidepressants, sedatives, narcotic pain relievers, and alcohol. ${ }^{128}$

In the clinical study for the evaluation of interactions between ebastine and ethanol, Mattila et a ${ }^{108}$ evaluated the performance of volunteers by means of objective tests, such as digit symbol substitution, flicker fusion threshold, Maddox wing, nystagmus, simulated driving, and body balance. Subjective tests included VAS and questionnaires. Ebastine did not impair performance either objectively or subjectively. Ethanol impaired performance in most objective tests and produced clumsiness, muzziness, and mental slowness, while these effects were not increased or modified in any way by ebastine.

Using a very similar design to their ethanol-ebastine interaction study, Mattila et a ${ }^{107}$ performed a double-blind, crossover study in which ebastine $20 \mathrm{mg}$ or placebo were administered for 1 week each. On day 7 of both periods, volunteers were given diazepam $15 \mathrm{mg}$ and the interaction between diazepam and ebastine was assessed. Performance was assessed by objective tests (digit symbol substitution, flicker fusion threshold, Maddox wing, simulated driving, and body balance). Subjective tests included VAS and questionnaires. Diazepam produced impaired performance in objective tests, and volunteers experienced drowsiness, weakness, clumsiness, mental slowness and poor performance according to the VAS. Ebastine, again, did not modify or increase the effects elicited by diazepam.

Interestingly, there is a study where the measurement of central $\mathrm{H}_{1}$ receptor occupancy in humans after ebastine intake has been assessed. In a single-blind, randomized, crossover study performed by Tagawa et al ${ }^{119} \mathrm{H}_{1}$ receptor occupation by oral ebastine $10 \mathrm{mg},(+)$ chlorpheniramine $2 \mathrm{mg}$ and $6 \mathrm{mg}$ and placebo was studied using PET, in healthy volunteers. Thereafter, PET scans with $\left[{ }^{11} \mathrm{C}\right]$-doxepin, a potent $\mathrm{H}_{1}$ receptor antihistamine, were conducted near the tmax reported for both drugs ( 90 minutes scanning). The binding potential of doxepin $(\mathrm{BP}=\mathrm{Bmax} / \mathrm{Kd})$ for available brain $\mathrm{H}_{1}$ receptors was imaged on a voxel-by-voxel basis through graphical analysis and $\mathrm{H}_{1}$ receptor occupancy was calculated in several $\mathrm{H}_{1}$ receptor rich regions (mainly cortex, anterior cingulate cortex $[\mathrm{ACC}]$ and thalamus) using statistical 
parametric mapping (SPM96). $\mathrm{H}_{1}$ receptor occupancies were approximately $9.9,3.2$ and $14.4 \%$ in the ebastine $10 \mathrm{mg}$ group (cortex, ACC and thalamus, respectively), approximately $50.3(P<0.001,95 \% \mathrm{CI}$ for difference in the mean receptor occupancies: $26.6-54.3$ vs ebastine $) 49.2(P<0.001$, 95\% CI: $24.3-67.5$ vs ebastine $)$ and $49.7 \%(P<0.01,95 \%$ CI 14.8 to 55.9 vs ebastine) in (+) chlorpheniramine $2 \mathrm{mg}$. Comparisons against $(+)$ chlorpheniramine $6 \mathrm{mg}$ were in the same range and were also statistically different. Furthermore, receptor occupancies increased with increasing plasma concentrations of $(+)$ chlorpheniramine (cortex: $r=0.9021$ $[P<0.001]$; ACC: $\mathrm{r}=0.7483[P=0.0051]$; thalamus: $\mathrm{r}=0.5874[P=0.0446])$, but not with concentrations of carebastine. Worth mentioning is the fact that other second generation antihistamines, such as epinastine, terfenadine, azelastine, mequitizine and astemizole, occupy $10 \%$ to $30 \%$ of brain $\mathrm{H}_{1}$ receptors. ${ }^{129}$

The lack of CNS effects is one of the characteristics that has been most thoroughly and satisfactorily assessed for ebastine. In vitro, in vivo, and clinical studies evaluating subjective and objective variables have made it clear that ebastine does not produce sedation at therapeutic doses. Drug interaction studies with classical CNS depressants have also discarded a synergistic effect. Furthermore, neuroimaging studies have now added to formerly available clinical evidence.

\section{Pharmacological approach}

\section{Receptor antagonism or inverse agonism}

The $H_{1}$ receptors belong to the superfamily of $G$ protein receptors (GPCRs) and are encoded on human chromosome 3. The cloning and expression of these elements by recombinant cells has allowed us to know that these receptors exhibit spontaneous activation of their intracellular messengers, requiring no binding by an agonist at surface level to be in an active state. This "constitutive activity" is attributable to an active and an inactive conformation coexisting in equilibrium. ${ }^{8}$ As a result, the drugs that act upon these receptors have been reclassified. Accordingly, if the ligand stabilizes the active conformation, then the drug is an agonist, whereas if the inactive conformation is stabilized, the drug is said to be an inverse agonist. ${ }^{71}$ In this sense, histamine is an agonist and $\mathrm{H}_{1}$ antihistamines are inverse agonists, rather than $\mathrm{H}_{1}$ receptor antagonists. ${ }^{39}$ Until now, all existing $\mathrm{H}_{1}$ antihistamines evaluated have proved to be inverse agonists. ${ }^{39}$ The advantages or disadvantages to develop a real $\mathrm{H}_{1}$ receptor antagonist instead of an inverse agonist are not yet clearly established.

\section{$\mathrm{H}_{3}$ receptors}

$\mathrm{H}_{3}$ receptors, first described in 1983, have been reported to play a role as autoreceptors in the regulation of histamine synthesis and release from tissue nerve. ${ }^{130}$ Localization studies in rodents have shown predominance in distinct regions of CNS, such as cerebral cortex, hippocampus, amygdala, nucleus accumbens, globus pallidus, striatum, and hypothalamus. Peripherally, these receptors have been identified in the gastrointestinal tract, airways, and cardiovascular system. The fact that $\mathrm{H}_{3}$ receptors are expressed in postganglionic cholinergic nerves in human bronchi has suggested that their stimulation may act as a protective mechanism against excessive bronchoconstriction.

Several centrally acting imidazole and nonimidazole based antagonists and inverse agonists have been studied in recent years for myriad conditions (eg, cognitive impairment, narcolepsy, obesity, diabetes mellitus, and neuropathic pain). ${ }^{131}$ Peripherally acting hybrid structures are created by combining histamine $\mathrm{H}_{1}$ with $\mathrm{H}_{3}$ pharmacophores to treat nasal congestion in allergic rhinitis, ${ }^{131}$ as it has been suggested that cutaneous itch and nasal congestion may be mediated both the $\mathrm{H}_{1}$ and $\mathrm{H}_{3}$ receptors. ${ }^{132-134}$

Combinations with $\mathrm{H}_{1}$ antihistamines have been reported in the field of imidazole and non-imidazole containing ligands. ${ }^{131}$ A ketopiperazine compound, GW-784568X (GlaxoSmithKline), is now patented and has already passed a clinical phase I/II study aiming to assess the safety and efficacy of intranasal application in patients with allergic rhinitis. ${ }^{131}$ Currently, GlaxoSmithKline's pipeline lists 2 histamine $\mathrm{H}_{1} / \mathrm{H}_{3}$ dual antagonists (GSK1004723 and GSK835726) in phase II of clinical development, targeted on allergic rhinitis. ${ }^{135}$ GSK 1004723 has already been administered intranasally in a phase I clinical trial, while GSK835726 is planned for a similar study. ${ }^{131}$ The success of this approach will be known shortly.

\section{$\mathrm{H}_{4}$ receptors}

A fourth histamine receptor $\left(\mathrm{H}_{4}\right)$ with very high affinity for histamine has recently been described. ${ }^{136,137}$ Its presence on eosinophils had been suggested previously. ${ }^{138-140}$ but it had not been identified as such. ${ }^{37}$ Compared with the $\mathrm{H}_{1}$ and $\mathrm{H}_{2}$ receptors, the $\mathrm{H}_{4}$ receptor is chiefly found in dendritic cells, mast cells, eosinophils, monocytes, basophils, and T cells, suggesting perhaps an interesting target for drug development.

The antihistamines that are currently used in the clinic have little, if any, affinity for the $\mathrm{H}_{4}$ receptor. However, it has been observed that this receptor is involved in inflammatory and immunomodulatory responses in vitro and in vivo. ${ }^{37}$ 
It has been demonstrated, for instance, that histamine acting through $\mathrm{H}_{4}$ receptors can induce chemotaxis of murine mast cells in vitro. ${ }^{141}$ Moreover, in vivo redistribution of mast cells to the tracheal epithelium has been successfully blocked by systemic administration of the $\mathrm{H}_{4}$ receptor antihistamine JNJ $7777120 .{ }^{142}$ It has been hypothesized that this latter effect is probably linked to the epithelial lining of the nasal mucosa in rhinitic responses to allergens. ${ }^{143,144}$ Additionally, activation of $\mathrm{H}_{4}$ receptors can induce chemotaxis of human eosinophils and dendritic cells, ${ }^{145,146}$ and in human mast-cell precursors this activation can synergize with other chemoatractants, ${ }^{138,147,148}$ such as CXCL12, a constitutive chemokine (ligand of CXCR4 and CXCR7) that is expressed in the skin and airway epithelium and plays a significant role in allergic airway diseases. $^{149,150}$

All the above described properties, and the emerging role of the $\mathrm{H}_{4}$ receptor in inflammation, have spurred new interest in the functions of histamine in inflammation, allergy, and autoimmune diseases. ${ }^{37}$ The apparent overlap in the functions of $\mathrm{H}_{1}$ and $\mathrm{H} 4$ receptors suggests that $\mathrm{H}_{4}$ receptor antihistamines could perhaps work in synergy with $\mathrm{H}_{1}$ receptor antihistamines for the relief of conditions such as asthma, a therapeutic area that has eluded $\mathrm{H}_{1}$ antihistamines to date. ${ }^{37}$

\section{Conclusions}

Current evidence shows that like other second-generation $\mathrm{H}_{1}$ antihistamines, ebastine can modulate the allergic inflammatory process, and that this property might be directly linked to the amelioration of nasal congestion. To corroborate this putative effect, a clinical trial with one or more positive comparators and placebo is needed.

For potency, efficacy, and effectiveness, ebastine has shown interesting properties in relation to other antihistamines, although their therapeutic relevance has not been satisfactorily demonstrated. In other words, ebastine does not differ as much as would be needed to be considered a third-generation agent.

Despite initial concerns by the FDA, clinical trials and clinical evidence from the clinical development and postmarketing stages have provided sufficient evidence to eliminate any major cardiac toxicity problem when the drug is used at the recommended doses. In retrospect, a thorough QT/QTc study, as currently defined, might have provided valuable information on the cardiac safety of ebastine and possibly would have ruled out the need for further studies.

Drug interactions after co-administration of ebastine with a number of other drugs have been correctly explored, in particular, CYP3A4 inhibitors or drugs with sedative effects.
Results have demonstrated that there seems to be no danger of clinically relevant drug interactions.

A lack of CNS effects has been correctly and exhaustively studied. Ebastine does not produce sedation at therapeutic doses, and drug interaction studies with classical CNS depressants have also eliminated a synergistic effect. Neuroimaging studies have added to the available clinical evidence.

Recently, other research lines have been investigated to obtain novel agents. For instance, the potential overlap of functions between $\mathrm{H}_{1}$ and $\mathrm{H}_{4}$ receptors has spurred new hope for the development of a new generation of antihistamines. In this regard, hybrid agents are being tested.

In conclusion, ebastine is $\mathrm{a}_{1}$ antihistamine with an interesting and widely proven therapeutic profile. It is one of the best documented second-generation antihistamines. However, taking CONGA recommendations into account, its classification as a third-generation antihistamine is far from applicable. It is still going to be some time before a novel agent, meriting the denomination of a third-generation agent, is developed.

\section{Acknowledgments}

We would like to thank Carolyn Newey for help with the English editing of the paper.

\section{Disclosures}

The authors declare no conflicts of interest.

\section{References}

1. Kay AB. Allergy and allergic diseases. First of two parts. NEngl J Med. 2001;344:30-37.

2. Dale HH, Laidlaw PP. Histamine shock. J Physiol. 1919;52:355-390.

3. Buendia E. Ebastine in context. Introduction. Drugs. 1996;52 Suppl 1:1-7.

4. Bovet D. The relationships between isosterism and competitive phenomena in the field of drug therapy of the autonomic nervous system and that of the neuromuscular transmission - Nobel lecture, 1957. http:// nobelprize.org/nobel_prizes/medicine/laureates/1957/bovet-lecture.pdf. Accessed 29 January, 2009.

5. Bovet $\mathrm{D}$. Introduction to antihistamine agents and antergan derivatives. Ann NY Acad Sci. 1950;50:1089-1126.

6. Staub AM. Recherches sur quelques bases synthétiques antagonistes de 1'histamine. Ann Inst Pasteur. 1939;63:400-436.

7. Holgate ST, Canonica GW, Simons FE, et al. Consensus Group on New-Generation Antihistamines (CONGA): present status and recommendations. Clin Exp Allergy. 2003;33:1305-1324.

8. Nettis E, Colanardi MC, Ferrannini A, Tursi A. Antihistamines as important tools for regulating inflammation. Curr Med Chem. 2005;4:81-89.

9. Mattila MJ, Paakkari I. Variations among non-sedating antihistamines: are there real differences? Eur J Clin Pharmacol. 1999;55:85-93.

10. Woosley RL. Cardiac actions of antihistamines. Annu Rev Pharmacol Toxicol. 1996;36:233-252.

11. Woosley RL, Chen Y, Freiman JP, Gillis RA. Mechanism of the cardiotoxic actions of terfenadine. JAMA. 1993;269:1532-1536.

12. ICH/CHMP. ICH Topic S7B: Nonclinical Evaluation of the Potential for Delayed Ventricular Repolarization (QT Interval Prolongation) by Human Pharmaceuticals, 2005. http://www.ich.org/LOB/media/ MEDIA2192.pdf. Accessed 28 July, 2009. 
13. ICH/CHMP. ICH Topic E14: The Clinical Evaluation of QT/QTe Interval Prolongation and Proarrhythmic Potential for Non-Antiarrhythmic Drugs - Note for guidance on the clinical evaluation of QT/QTc interval prolongation and proarrhythmic potential for nonantiarrhythmic drugs, 2005. http://www.ich.org/LOB/media/MEDIA1476.pdf. Accessed 28 July, 2009.

14. Antonijoan R, Garcia-Gea C, Puntes M, et al. Comparison of inhibition of cutaneous histamine reaction of ebastine fast-dissolving tablet $(20 \mathrm{mg})$ versus desloratadine capsule $(5 \mathrm{mg})$ : a randomized, double-blind, double-dummy, placebo-controlled, three-period crossover study in healthy, nonatopic adults. Clin Ther. 2007; 29:814-822.

15. Slater JW, Zechnich AD, Haxby DG. Second-generation antihistamines: a comparative review. Drugs. 1999;57:31-47.

16. Roberts DJ. Towards the optimal antihistamine: studies with ebastine. Inflamm Res. 1998;47 Suppl 1:S36-S37.

17. Hanifin JM. The role of antihistamines in atopic dermatitis. J Allergy Clin Immunol. 1990;86:666-669.

18. Van Cauwenberge $\mathrm{P}$, De Belder $\mathrm{T}$, Sys L. A review of the second-generation antihistamine ebastine for the treatment of allergic disorders. Expert Opin Pharmacother. 2004;5:1807-1813.

19. Sastre J. Ebastine in allergic rhinitis and chronic idiopathic urticaria. Allergy. 2008;63 Supp1 89:1-20.

20. Storms WW. Clinical studies of the efficacy and tolerability of ebastine 10 or $20 \mathrm{mg}$ once daily in the treatment of seasonal allergic rhinitis in the US. Drugs. 1996;52 Suppl 1:20-25.

21. Ratner P, Falques M, Chuecos F, et al. Meta-analysis of the efficacy of ebastine $20 \mathrm{mg}$ compared to loratadine $10 \mathrm{mg}$ and placebo in the symptomatic treatment of seasonal allergic rhinitis. Int Arch Allergy Immunol. 2005;138:312-318.

22. Ratner P, Hampel F Jr, Van Bavel J, Howland W 3rd. Efficacy and safety of ebastine $20 \mathrm{mg}$ compared to loratadine $10 \mathrm{mg}$ once daily in the treatment of seasonal allergic rhinitis: a randomized, double-blind, placebo-controlled study. Int Arch Allergy Immunol. 2004;133:371-379.

23. Ratner PH, Lim JC, Georges GC. Comparison of once-daily ebastine $20 \mathrm{mg}$, ebastine $10 \mathrm{mg}$, loratadine $10 \mathrm{mg}$, and placebo in the treatment of seasonal allergic rhinitis. The Ebastine Study Group. J Allergy Clin Immunol. 2000;105:1101-1107.

24. Frank H Jr, Gillen M, Rohatagi SS, Lim J, George G. A double-blind, placebo-controlled study of the efficacy and safety of ebastine $20 \mathrm{mg}$ once daily given with and without food in the treatment of seasonal allergic rhinitis. J Clin Pharmacol. 2002;42:1097-1104.

25. Bousquet J, Gaudano EM, Palma Carlos AG, Staudinger H. A 12-week, placebo-controlled study of the efficacy and safety of ebastine, 10 and $20 \mathrm{mg}$ once daily, in the treatment of perennial allergic rhinitis. Multicentre Study Group. Allergy. 1999;54:562-568.

26. Picado Valles C, Cadahia Garcia A, Cistero Bahima A, Cano Cantudo L, Sanz Amaro A, Zayas Sanza JM. Ebastine in perennial allergic rhinitis. Ann Allergy. 1991;67:615-618.

27. Peyrí J, Vidal J, Marrón J, et al. Ebastine in chronic urticaria: A doubleblind placebo controlled study. J Dermatol Treat. 1991:51-53.

28. Kalis B. Double-blind multicentre comparative study of ebastine, terfenadine and placebo in the treatment of chronic idiopathic urticaria in adults. Drugs. 1996;52 Suppl 1:30-34.

29. Magerl M, Schmolke J, Siebenhaar F, Zuberbier T, Metz M, Maurer M. Acquired cold urticaria symptoms can be safely prevented by ebastine. Allergy. 2007;62:1465-1468.

30. Magerl M, Schmolke J, Siebenhaar F, Zuberbier T, Metz M, Maurer M. Dermographic urticaria symptoms can be safely prevented by ebastine. [abstract plus poster] World Allergy Congress, Bangkok, Dec 2-6, 2007.

31. Horiguchi T, Tachikawa S, Kasahara J, Shiga M, Kondo R, Miyazaki H. Effect of ebastine on serum eosinophil cationic protein levels in patients with bronchial asthma. Clin Drug Invest. 1999;17.

32. Karppinen A, Petman L, Jekunen A, Kautiainen H, Vaalasti A, Reunala T. Treatment of mosquito bites with ebastine: a field trial. Acta Derm Venereol. 2000;80:114-116.
33. Robert M, Llorens M, Garcia E, Luria X. Efficacy and tolerability of ebastine $10 \mathrm{mg}$ plus pseudoephedrine $120 \mathrm{mg}$ in the symptomatic relief of the common cold. Eur J Intern Med. 2004;15:242-247.

34. Hurst M, Spencer CM. Ebastine: an update of its use in allergic disorders. Drugs. 2000;59:981-1006.

35. Wiseman LR, Faulds D. Ebastine. a review of its pharmacological properties and clinical efficacy in the treatment of allergic disorders. Drugs. 1996;51:260-277.

36. Roberts DJ. A preclinical overview of ebastine. Studies on the pharmacological properties of a novel histamine $\mathrm{H} 1$ receptor antagonist. Drugs. 1996;52 Suppl 1:8-14.

37. Thurmond RL, Gelfand EW, Dunford PJ. The role of histamine H1 and H4 receptors in allergic inflammation: the search for new antihistamines. Nat Rev Drug Discov. 2008;7:41-53.

38. Scadding GK. Predicting and Establishing the Clinical Efficacy of a Histamine H1 Receptor antagonist. Clin Drug Invest. 2005;25:153-164.

39. Simons FE. Advances in H1-antihistamines. N Engl J Med. 2004;351: 2203-2217.

40. Roumestan C, Henriquet C, Gougat C, et al. Histamine H1-receptor antagonists inhibit nuclear factor-kappaB and activator protein-1 activities via H1-receptor-dependent and -independent mechanisms. Clin Exp Allergy. 2008;38:947-956.

41. Arnold R, Rihoux J, Konig W. Cetirizine counter-regulates interleukin-8 release from human epithelial cells (A549). Clin Exp Allergy. 1999;29:1681-1691.

42. Papi A, Papadopoulos NG, Stanciu LA, Degitz K, Holgate ST, Johnston SL. Effect of desloratadine and loratadine on rhinovirusinduced intercellular adhesion molecule 1 upregulation and promoter activation in respiratory epithelial cells. J Allergy Clin Immunol. 2001;108:221-228.

43. Yoneda K, Yamamoto T, Ueta E, Osaki T. Suppression by azelastine hydrochloride of NF-kappa B activation involved in generation of cytokines and nitric oxide. Jpn J Pharmacol. 1997;73:145-153.

44. Aoki Y, Qiu D, Zhao GH, Kao PN. Leukotriene B4 mediates histamine induction of NF-kappaB and IL-8 in human bronchial epithelial cells. Am J Physiol. 1998;274:L1030-L1039.

45. Megson AC, Walker EM, Hill SJ. Role of protein kinase Calpha in signaling from the histamine $\mathrm{H}(1)$ receptor to the nucleus. $\mathrm{Mol}$ Pharmacol. 2001;59:1012-1021.

46. Bakker RA, Schoonus SB, Smit MJ, Timmerman H, Leurs R. Histamine $\mathrm{H}(1)$-receptor activation of nuclear factor-kappa B: roles for $\mathrm{G}$ beta gamma- and G alpha(q/11)-subunits in constitutive and agonistmediated signaling. Mol Pharmacol. 2001;60:1133-1142.

47. Devalia JL, Rusznak C, Davies RJ. Allergen/irritant interaction - its role in sensitization and allergic disease. Allergy. 1998;53:335-345.

48. Campbell A, MichelFB, Bremard-Oury C, Crampette L, Bousquet J. Overview of allergic mechanisms. Ebastine has more than an antihistamine effect. Drugs. 1996;52 Suppl 1:15-19.

49. Nori M, Iwata S, Munakata Y, et al. Ebastine inhibits T cell migration, production of Th2-type cytokines and proinflammatory cytokines. Clin Exp Allergy. 2003;33:1544-1554.

50. Ciprandi G, Cirillo I, Pistorio A, Di Gioacchino M, Fenoglio D. Ebastine increases IFN-gamma production in patients with persistent allergic rhinitis. J Biol Regul Homeost Agents. 2009;23:31-36.

51. Horak F. Impact and modulation of nasal obstruction. Allergy. 2002;57 Suppl 75:25-28.

52. Ratner P, Hampel F Jr, Gispert J. Efficacy of ebastine in the control of nasal congestion associated with allergic rhinitis. Methods Find Exp Clin Pharmacol. 2003;25:111-115.

53. Ciprandi G, Cirillo I, Mora F, La Rosa M. Ebastine improves nasal symptoms and airflow and affects response to decongestion test in patients with persistent allergic rhinitis: a pilot study. Allergy Asthma Proc. 2007;28:578-581.

54. Howarth PH. Assessment of antihistamine efficacy and potency. Clin Exp Allergy. 1999;29 Suppl 3:87-97.

55. FDA. Pulmonary-Allergy Drugs Advisory Committee: Clinical Briefing Document-NDA 20-959-Ebastine 10 and $20 \mathrm{mg}$ tablets for SAR and PAR. Vol. 2009: Almirall Prodesfarma, 2002. 
56. Llupia J, Gras J, Llenas J. Comparative antiallergic effects of second-generation $\mathrm{H} 1$-antihistamines ebastine, cetirizine and loratadine in preclinical models. Arzneimittelforschung. 2003;53:93-97.

57. Frossard N, Benabdesselam O, Purohit A, Mounedji N, Pauli G. Activity of ebastine (10 and $20 \mathrm{mg}$ ) and cetirizine at 24 hours of a steady state treatment in the skin of healthy volunteers. Fundam Clin Pharmacol. 2000;14:409-413.

58. Barbanoj MJ, Antonijoan RM, Garcia-Gea C, et al. A study comparing the inhibitory effects of single and repeated oral doses of ebastine and fexofenadine against histamine-induced skin reactivity. Int Arch Allergy Immunol. 2003;132:263-267.

59. Gispert J, Antonijoan R, Barbanoj M, et al. Efficacy of ebastine, cetirizine, and loratadine in histamine cutaneous challenges. Ann Allergy Asthma Immunol. 2002;89:259-264.

60. Frossard N, Vital-Durand D, Mounedji N, Valleteau A. Duration of the antihistaminic effect after discontinuation of ebastine. Allergy. 2001;56:553-557.

61. van Steekelenburg J, Clement PA, Beel MH. Comparison of five new antihistamines (H1-receptor antagonists) in patients with allergic rhinitis using nasal provocation studies and skin tests. Allergy. 2002;57:346-350.

62. Antonijoan RM, Garcia-Gea C, Puntes M, et al. A comparison of ebastine $10 \mathrm{mg}$ fast-dissolving tablet with oral desloratadine and placebo in inhibiting the cutaneous reaction to histamine in healthy adults. Clin Drug Investig. 2007;27:453-461.

63. Llenas J, Bou J, Massingham R. Preclinical safety studies with ebastine II. Pharmacological effects on the cardiovascular system. Drugs Today. 1992;28:29-34.

64. Ankier SI, Warrington SJ. A double-blind placebo-controlled study of the efficacy and tolerability of ebastine against hayfever in general practice patients. J Intern Med. 1989;226:453-458.

65. De Molina M, Cadahia Garcia A, Cano Cantudo L, Sanz Amaro A. Efficacy and tolerability of ebastine at two dose levels in the treatment of seasonal allergic rhinitis. Drug Invest. 1989;1:40-46.

66. Pelaez A. Clinical efficacy of ebastine in the treatment and prevention of seasonal allergic rhinitis. Drugs. 1996;52 Suppl 1:35-38.

67. Gehanno P, Bremard-Oury C, Zeisser P. Comparison of ebastine to cetirizine in seasonal allergic rhinitis in adults. Ann Allergy Asthma Immunol. 1996;76:507-512

68. Hampel F Jr, Howland W, 3rd, Van Bavel J, Ratner P. A randomized, double-blind, placebo-controlled study comparing the efficacy and safety of ebastine $(20 \mathrm{mg}$ and $10 \mathrm{mg}$ ) to loratadine $10 \mathrm{mg}$ once daily in the treatment of seasonal allergic rhinitis. J Investig Allergol Clin Immunol. 2004;14:56-63.

69. Murris-Espin M, Melac M, Charpentier JC, Didier A. Comparison of efficacy and safety of cetirizine and ebastine in patients with perennial allergic rhinitis. Ann Allergy Asthma Immunol. 1998;80:399-403.

70. Davies RJ. Efficacy and tolerability comparison of ebastine 10 and $20 \mathrm{mg}$ with loratadine $10 \mathrm{mg}$ : a double-blind, randomised study in patients with perennial allergic rhinitis. Clin Drug Investig. 1998;16:413-420.

71. del Cuvillo A, Mullol J, Bartra J, et al. Comparative pharmacology of the H1 antihistamines. J Investig Allergol Clin Immunol. 2006;16 Suppl 1:3-12.

72. Peyrí J, Vidal J, Marrón J, Fonseca E, Suárez E, Ledo A. Ebastine in chronic urticaria: a double-blind placebo-controlled study.J Dermatolog Treat. 1991;2:51-53.

73. Roger A, Fortea J, Artés M, Montilla L. Preferred attributes of the new fast dissolving tablet (FDT) formulation of ebastine in patients with allergy. J Outcomes Res. 2006;10:13-22.

74. Roger A, Fortea J, Mora F, Artés M. Patient assessment of onset of action and overall satisfaction with ebastine fast-dissolving tablets in allergic rhinitis. Expert Rev Pharmacoecon Outcomes Res. 2008;8:337-342.

75. Roger A, Fortea J, Mora S, Artés M. Ebastine fast-dissolving tablets vs regular tablets: acceptability and preference in patients with allergic rhinitis. Rev Clin Pharmacol. 2008;1:381-389.

76. Roger A, Fortea J, Plazas Fernández MJ, Asensio D, Mora S, González Rojas N. Evaluation of the patient's satisfaction with the new ebastine formulation in patients suffering from allergic rhinitis [abstract 619]. Allergy. 2007;62:225.
77. Roger A, Plazas Fernández MJ, Galván Cervera J, Heras Navarro J, Artés M, Gabarron Hortal E. Acceptance survey of a fast dissolving tablet pharmaceutical formulation in allergic patients. Satisfaction and expectancies. Allergol et Immunopathol. 2006;34:107-112.

78. Roger A, Plazas Fernández MJ, Galván Cervera J, Heras Navarro J, Artés M, Montilla L. Aceptación, expectativas y satisfacción de la formulación FLAS para el tratamiento de la alergia. Farmacología. 2007;372:2-10.

79. Katyal VK, Jagdish, Choudhary D, Choudhary JD. Occurrence of torsade de pointes with use of astemizole. Indian Heart J. 1994;46:181-182.

80. June RA, Nasr I. Torsades de pointes with terfenadine ingestion. Am J Emerg Med. 1997;15:542-543.

81. Soldovieri MV, Miceli F, Taglialatela M. Cardiotoxic effects of antihistamines: from basics to clinics (...and back). Chem Res Toxicol. 2008;21:997-1004.

82. Moss AJ, Chaikin P, Garcia JD, Gillen M, Roberts DJ, Morganroth J. A review of the cardiac systemic side-effects of antihistamines: ebastine. Clin Exp Allergy. 1999;29 Suppl 3:200-205.

83. Segarra V, Lopez M, Ryder H, Palacios JM, Roberts DJ. Computer-assisted comparison of the structural and electronic dispositions of ebastine and terfenadine. Drug Saf. 1999;21 Suppl 1:45-61; discussion 81-87.

84. Ko CM, Ducic I, Fan J, Shuba YM, Morad M. Suppression of mammalian $\mathrm{K}+$ channel family by ebastine. J Pharmacol Exp Ther. 1997;281:233-244.

85. Llenas J, Gras J, Palacios JM, Roberts DJ. Comparative intravenous effects of terfenadine and ebastine on QTc prolongation in anaesthetized guinea pigs. J Allergy Clin Immunol. 1999;Suppl 1:S256.

86. Hey JA, del Prado M, Sherwood J, Kreutner W, Egan RW. The guinea pig model for assessing cardiotoxic proclivities of second generation antihistamines. Arzneimittelforschung. 1996;46:834-837.

87. Hey JA, del Prado M, Egan RW, Kreutner W. Terfenadine, astemizole, and ebastine produce QTc interval prolongation in an experimental model predictive of adverse clinical ECG effects. Ann Allergy Asthma Immunol. 1996;76:476.

88. Hey JA, del Prado M, Kreutner W, Egan RW. Cardiotoxic and drug interaction profile of the second generation antihistamines ebastine and terfenadine in an experimental animal model of torsade de pointes. Arzneimittelforschung. 1996;46:159-163.

89. Hey JA, del Prado M, Sherwood J, Kreutner W, Egan RW. Comparative analysis of the cardiotoxicity proclivities of second generation antihistamines in an experimental model predictive of adverse clinical ECG effects. Arzneimittelforschung. 1996;46:153-158.

90. Gras J, Llenas J. Effects of H1 antihistamines on animal models of QTc prolongation. Drug Saf. 1999;21 Suppl 1:39-44; discussion 81-87.

91. Gras J, Llenas J, Palacios JM, Roberts DJ. The role of ketoconazole in the QTc interval prolonging effects of $\mathrm{H} 1$-antihistamines in a guinea-pig model of arrhythmogenicity. Br J Pharmacol. 1996;119:187-188.

92. Gillen MS, Miller B, Chaikin P, Morganroth J. Effects of supratherapeutic doses of ebastine and terfenadine on the QT interval. $\mathrm{Br} J$ Clin Pharmacol. 2001;52:201-204.

93. Malik M. Problems of heart rate correction in assessment of druginduced QT interval prolongation. J Cardiovasc Electrophysiol. 2001;12:411-420.

94. Gispert J, Esbri R, Garcia E. Ebastine has no effect on QTc interval at doses up to 50 times the therapeutic dose [abstract 779]. Allergy. 2002;57:243-244

95. Chaikin P, Gillen MS, Malik M, Pentikis H, Rhodes GR, Roberts DJ. Co-administration of ketoconazole with H1-antagonists ebastine and loratadine in healthy subjects: pharmacokinetic and pharmacodynamic effects. Br J Clin Pharmacol. 2005;59:346-354.

96. Bruno R, Baille P, Rhodes GR, Gillen M, Chaikin P, Morganroth J. An evaluation of the pharmacokinetic/pharmacocynamic (PIC/PD) relationships with ebastine at high exposures. J Clin Pharmacol. 1998;38:874.

97. Wilson J, Huang MY, Argenti D. Comparative pharmacokinetics of carebastine/ebastine in moderately renally impaired and healthy volunteers following sinlge dose of ebastine. Pharm Res. 1993;10 (Suppl):S391. 
98. Huang MY, Wilson J, Argenti D, Heald D, Ziemniak J. Comparative pharmacokinetics of ebastine/carebastine in liver cirrhosis and healthy volunteers following administration of a $10 \mathrm{mg}$ ebastine tablet. Pharm Res. 1993;10 (Suppl):S390.

99. Huang MY, Argenti D, Wilson J, Garcia J, Heald D. Pharmacokinetics and electrocardiographic effect of ebastine in young versus elderly healthy subjects. Am J Ther. 1998;5:153-158.

100. Bartra J, Valero AL, del Cuvillo A, et al. Interactions of the H1 antihistamines. J Investig Allergol Clin Immunol. 2006;16 Suppl 1:29-36.

101. Fujii T, Matsumoto S, Amejima H, et al. Absorption, distribution, metabolism and excretion of [14C] ebastine after a single administration in rats. Arzneimittelforschung. 1994;44:527-538.

102. Hashizume T, Mise M, Terauchi Y, et al. N-Dealkylation and hydroxylation of ebastine by human liver cytochrome P450. Drug Metab Dispos. 1998;26:566-571.

103. Hashizume T, Mise M, Matsumoto S, et al. A novel cytochrome P450 enzyme responsible for the metabolism of ebastine in monkey small intestine. Drug Metab Dispos. 2001;29:798-805.

104. Liu KH, Kim MG, Lee DJ, et al. Characterization of ebastine, hydroxyebastine, and carebastine metabolism by human liver microsomes and expressed cytochrome P450 enzymes: major roles for CYP2J2 and CYP3A. Drug Metab Dispos. 2006;34:1793-1797.

105. van Rooij J, Schoemaker HC, Bruno R, Reinhoudt JF, Breimer DD, Cohen AF. Cimetidine does not influence the metabolism of the H1-receptor antagonist ebastine to its active metabolite carebastine. Br J Clin Pharmacol. 1993;35:661-663.

106. García Vallejo FJ, Velert Vila MM, Marco Sanz M, Fernández Julián EN. Empleo simultáneo de antihistamínicos H1 y anticoagulantes orales. Acta Otorrinolaringol Esp. 2001;52:442-445.

107. Mattila MJ, Aranko K, Kuitunen T. Diazepam effects on the performance of healthy subjects are not enhanced by treatment with the antihistamine ebastine. Br J Clin Pharmacol. 1993;35:272-277.

108. Mattila MJ, Kuitunen T, Pletan Y. Lack of pharmacodynamic and pharmacokinetic interactions of the antihistamine ebastine with ethanol in healthy subjects. Eur J Clin Pharmacol. 1992;43: 179-184.

109. Tamai I, Kido Y, Yamashita J, Sai Y, Tsuji A. Blood-brain barrier transport of H1-antagonist ebastine and its metabolite carebastine. J Drug Target. 2000;8:383-393.

110. Cimbura G, Lucas DM, Bennett RC, Warren RA, Simpson HM. Incidence and toxicological aspects of drugs detected in 484 fatally injured drivers and pedestrians in Ontario. J Forensic Sci. 1982;27: 855-867.

111. Fireman P. Treatment of allergic rhinitis: effect on occupation productivity and work force costs. Allergy Asthma Proc. 1997;18:63-67.

112. Gilmore TM, Alexander BH, Mueller BA, Rivara FP. Occupational injuries and medication use. Am J Ind Med. 1996;30:234-239.

113. Vuurman EF, van Veggel LM, Uiterwijk MM, Leutner D, O'Hanlon JF. Seasonal allergic rhinitis and antihistamine effects on children's learning. Ann Allergy. 1993;71:121-126.

114. Goldberg MJ, Spector R, Chiang CK. Transport of diphenhydramine in the central nervous system. J Pharmacol Exp Ther. 1987;240: 717-722.

115. Yanai K, Ryu JH, Watanabe T, et al. Positron emission tomographic study of central histamine H1-receptor occupancy in human subjects treated with epinastine, a second-generation antihistamine. Methods Find Exp Clin Pharmacol. 1995;17 Suppl C:64-69.

116. Vincent J, Sumner DJ, Reid JL. Ebastine: the effect of a new antihistamine on psychomotor performance and autonomic responses in healthy subjects. Br J Clin Pharmacol. 1988;26:503-508.

117. Fujii T, Tanaka K, Matsumoto S, et al. Absorption, distribution, metabolism and excretion of [14C]ebastine after repeated oral administration in rats. Arzneimittelforschung. 1994;44:538-543.

118. Yamaguchi T, Hashizume T, Matsuda M, et al. Pharmacokinetics of the H1-receptor antagonist ebastine and its active metabolite carebastine in healthy subjects. Arzneimittelforschung. 1994;44: $59-64$.
119. Tagawa M, Kano M, Okamura N, et al. Neuroimaging of histamine H1-receptor occupancy in human brain by positron emission tomography (PET): a comparative study of ebastine, a second-generation antihistamine, and (+)-chlorpheniramine, a classical antihistamine. Br J Clin Pharmacol. 2001;52:501-509.

120. Hopes H, Meuret GH, Ungethum W, Leopold G, Wiemann H. Placebo controlled comparison of acute effects of ebastine and clemastine on performance and EEG. Eur J Clin Pharmacol. 1992;42:55-59.

121. Hindmarch, Shamsi Z. The effects of single and repeated administration of ebastine on cognition and psychomotor performance in comparison to triprolidine and placebo in healthy volunteers. Curr Med Res Opin. 2001;17:273-281.

122. Tagawa M, Kano M, Okamura N, et al. Differential cognitive effects of ebastine and (+)-chlorpheniramine in healthy subjects: correlation between cognitive impairment and plasma drug concentration. $\mathrm{Br} J$ Clin Pharmacol. 2002;53:296-304.

123. Brookhuis KA, De Vries G, De Waard D. Acute and subchronic effects of the H1-histamine receptor antagonist ebastine in 10, 20 and $30 \mathrm{mg}$ dose, and triprolidine $10 \mathrm{mg}$ on car driving performance. $\mathrm{Br} J$ Clin Pharmacol. 1993;36:67-70.

124. Armstrong SC, Cozza KL, Oesterheld JR. Med-psych drug-drug interactions update. Psychosomatics. 2002;43:77-81

125. Armstrong SC, Cozza KL. Pharmacokinetic drug interactions of morphine, codeine, and their derivatives: theory and clinical reality, part I. Psychosomatics. 2003;44:167-171.

126. Bousquet J, Van Cauwenberge P, Khaltaev N. Allergic rhinitis and its impact on asthma. J Allergy Clin Immunol. 2001;108:S147-S334.

127. Casale TB, Blaiss MS, Gelfand E, et al. First do no harm: managing antihistamine impairment in patients with allergic rhinitis. $J$ Allergy Clin Immunol. 2003;111:S835-S842.

128. McDonald K, Trick L, Boyle J. Sedation and antihistamines: an update. Review of inter-drug differences using proportional impairment ratios. Hum Psychopharmacol. 2008;23:555-570.

129. Yanai K, Okamura N, Tagawa M, Itoh M, Watanabe T. New findings in pharmacological effects induced by antihistamines: from PET studies to knock-out mice. Clin Exp Allergy. 1999;29 Suppl 3:29-36; discussion 37-38.

130. Arrang JM, Garbarg M, Schwartz JC. Auto-inhibition of brain histamine release mediated by a novel class (H3) of histamine receptor. Nature. 1983;302:832-837.

131. Sander K, Kottke T, Stark H. Histamine H3 receptor antagonists go to clinics. Biol Pharm Bull. 2008;31:2163-2181.

132. McLeod RL, Mingo GG, Herczku C, et al. Combined histamine H1 and $\mathrm{H} 3$ receptor blockade produces nasal decongestion in an experimental model of nasal congestion. Am J Rhinol. 1999;13:391-399.

133. McLeod RL, Mingo GG, Kreutner W, Hey JA. Effect of combined histamine $\mathrm{H} 1$ and $\mathrm{H} 3$ receptor blockade on cutaneous microvascular permeability elicited by compound 48/80. Life Sci. 2005;76: 1787-1794.

134. Sugimoto Y, Iba Y, Nakamura Y, Kayasuga R, Kamei C. Pruritus-associated response mediated by cutaneous histamine $\mathrm{H} 3$ receptors. Clin Exp Allergy. 2004;34:456-459.

135. GlaxoSmithKline. Product Development Pipeline. Vol. 2009.

136. Liu C, Ma X, Jiang X, et al. Cloning and pharmacological characterization of a fourth histamine receptor $(\mathrm{H}(4))$ expressed in bone marrow. Mol Pharmacol. 2001;59:420-426.

137. Oda T, Morikawa N, Saito Y, Masuho Y, Matsumoto S. Molecular cloning and characterization of a novel type of histamine receptor preferentially expressed in leukocytes. J Biol Chem. 2000;275:36781-36786.

138. Clark RA, Gallin JI, Kaplan AP. The selective eosinophil chemotactic activity of histamine. $J$ Exp Med. 1975;142:1462-1476.

139. Raible DG, Lenahan T, Fayvilevich Y, Kosinski R, Schulman ES. Pharmacologic characterization of a novel histamine receptor on human eosinophils. Am J Respir Crit Care Med. 1994;149:1506-1511.

140. Raible DG, Schulman ES, DiMuzio J, Cardillo R, Post TJ. Mast cell mediators prostaglandin-D2 and histamine activate human eosinophils. J Immunol. 1992;148:3536-3542. 
141. Hofstra CL, Desai PJ, Thurmond RL, Fung-Leung WP. Histamine H4 receptor mediates chemotaxis and calcium mobilization of mast cells. J Pharmacol Exp Ther. 2003;305:1212-1221.

142. Thurmond RL, Desai PJ, Dunford PJ, et al. A potent and selective histamine $\mathrm{H} 4$ receptor antagonist with anti-inflammatory properties. J Pharmacol Exp Ther. 2004;309:404-413.

143. Slater A, Smallman LA, Drake-Lee AB. Increase in epithelial mast cell numbers in the nasal mucosa of patients with perennial allergic rhinitis. J Laryngol Otol. 1996;110:929-933.

144. Fokkens WJ, Godthelp T, Holm AF, et al. Dynamics of mast cells in the nasal mucosa of patients with allergic rhinitis and non-allergic controls: a biopsy study. Clin Exp Allergy. 1992;22:701-710.

145. Idzko M, la Sala A, Ferrari D, et al. Expression and function of histamine receptors in human monocyte-derived dendritic cells. J Allergy Clin Immunol. 2002;109:839-846.
146. Gutzmer R, Langer K, Lisewski M, et al. Expression and function of histamine receptors 1 and 2 on human monocytederived dendritic cells. J Allergy Clin Immunol. 2002;109: 524-531.

147. Ling P, Ngo K, Nguyen S, et al. Histamine H4 receptor mediates eosinophil chemotaxis with cell shape change and adhesion molecule upregulation. Br J Pharmacol. 2004;142:161-171.

148. Buckland KF, Williams TJ, Conroy DM. Histamine induces cytoskeletal changes in human eosinophils via the $\mathrm{H}(4)$ receptor. Br J Pharmacol. 2003;140:1117-1127.

149. Akdis CA. New insights into mechanisms of immunoregulation in 2007. J Allergy Clin Immunol. 2008;122:700-709.

150. Godot V, Arock M, Garcia G, et al. H4 histamine receptor mediates optimal migration of mast cell precursors to CXCL12. J Allergy Clin Immunol. 2007;120:827-834.

\section{Publish your work in this journal}

The Journal of Asthma and Allergy is an international, peer-reviewed open-access journal publishing original research, reports, editorials and commentaries on the following topics: Asthma; Pulmonary physiology; Asthma related clinical health; Clinical immunology and the immunological basis of disease; Pharmacological interventions and

Submit your manuscript here: http://www.dovepress.com/journal-of-asthma-and-allergy-journal

\section{Dovepress}

new therapies. Issues of patient safety and quality of care will also be considered. The manuscript management system is completely online and includes a very quick and fair peer-review system, which is all easy to use. Visit http://www.dovepress.com/testimonials.php to read real quotes from published authors. 